\title{
Does Planning Regulation Protect Independent Retailers?
}

\section{Citation}

Sadun, Raffaella. "Does Planning Regulation Protect Independent Retailers?" Review of Economics and Statistics (forthcoming).

\section{Published Version}

http://www.mitpressjournals.org/doi/abs/10.1162/REST_a_00492

\section{Permanent link}

http://nrs.harvard.edu/urn-3:HUL.InstRepos:17417215

\section{Terms of Use}

This article was downloaded from Harvard University's DASH repository, and is made available under the terms and conditions applicable to Open Access Policy Articles, as set forth at http:// nrs.harvard.edu/urn-3:HUL.InstRepos:dash.current.terms-of-use\#OAP

\section{Share Your Story}

The Harvard community has made this article openly available.

Please share how this access benefits you. Submit a story.

Accessibility 
H A R VARD D B U I N E S S S C H O O L

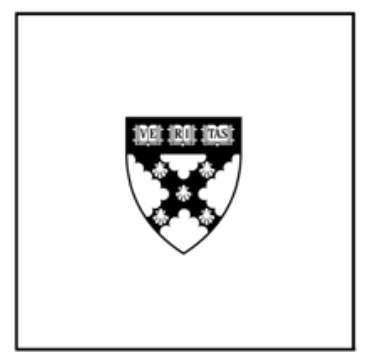

\section{Does Planning Regulation Protect Independent Retailers?}

Raffaella Sadun

\section{Working Paper}

$12-044$

December 19, 2013 


\section{DOES PLANNING REGULATION PROTECT INDEPENDENT RETAILERS?}

\section{Raffaella Sadun ${ }^{1}$}

\section{December 2013}

Abstract: Regulations aimed at curbing the entry of large retail stores have been introduced in many countries to protect independent retailers. Analyzing a planning reform launched in the United Kingdom in the 1990s, I show that independent retailers were actually harmed by the creation of entry barriers against large stores. Instead of simply reducing the number of new large stores entering a market, the entry barriers created the incentive for large retail chains to invest in smaller and more centrally located formats, which competed more directly with independents and accelerated their decline. Overall, these findings suggest that restricting the entry of large stores does not necessarily lead to a world with fewer stores, but one with different stores, with uncertain competitive effects on independent retailers.

Keywords: Zoning, Location, Retail, Regulation

JEL Classification: K2, L10, L81, L51

${ }^{1}$ Harvard Business School, Centre for Economic Performance, NBER and CEPR (email: rsadun@hbs.edu). This paper is a revised version of Chapter III of my PhD thesis. I wish to thank John Van Reenen for his invaluable advice. I am grateful to Emek Basker, Sharon Belenzon, Marianne Bertrand, Nick Bloom, Jim Dana, Peter Davies, Rachel Griffith, Haike Harmgart, Jonathan Haskel, Marco Manacorda, Steve Machin, Guy Michaels, Henry Overman, Steve Pischke, Steve Redding, Mark Schankerman, Philip Schmidt-Dengler, and participants in seminars at Columbia, Harvard, Kellogg, LSE, MIT, Wharton, Yale, and the ZEW "Workshop on the Retail Industry" for their useful comments. Disclaimer: This work contains statistical data from the Office of National Statistics (ONS), which is Crown copyright and reproduced with the permission of the controller of HMSO and Queens Printer for Scotland. The use of the ONS statistical data in this work does not imply the endorsement of the ONS in relation to the interpretation or analysis of the statistical data. 


\section{Introduction}

Planning regulations are often used to curb the entry of large out of town retail stores - also known as "big-boxes." These policies, which are widely adopted across OECD countries (Ennis 2008; Pilat 1997), find their justification in the need to prevent the possible negative externalities generated by big-boxes on local communities (e.g. congestion, damages to the environmental décor) and, in particular, to protect the survival of smaller retailers and the amenities they provide—-such as personalized and local service—from new sources of competitive pressure. ${ }^{1}$

In recent years, entry regulations have been severely criticized for their possible effects on the efficiency of the retail sector. Constraining the entry of big-boxes, it has been argued, could reduce economies of scale, and slow down the introduction of IT innovations complementary with large surfaces (Basker, Klimek, and Pham 2010; Holmes 2001; McKinsey Global Institute 1998; Schivardi and Viviano 2011). Furthermore, entry regulations could also hinder the reallocation of resources and employment between and within firms, which appear to be a major driver of productivity growth in the retail sector. $^{2}$

${ }^{1}$ For example, WalMartwatch, an interest group that challenges Wal-Mart expansion across the United States, reports on its website: "You can stop superstore sprawl with one sentence. Just amend your zoning code to place a limit on the size of buildings" (http://walmartwatch.com/battlemart/go/cat/zoning_regulations, retrieved on August 10th 2008).

${ }^{2}$ Foster, Haltiwanger, and Krizan (2006) document that between firms reallocation accounts for $90 \%$ of the impressive labor productivity growth experienced by the U.S. retail sector between 1990 and 2000, and that most of the reallocation dynamics are from small to large retail establishments. 
In spite of the wide interest generated by this debate, relatively little empirical evidence exists on the actual cost and benefits associated with planning regulations. In particular, the idea that restricting the entry of large retail stores can effectively change the nature of retail competition in favor of independent stores has received limited empirical investigation. ${ }^{3}$ This is primarily dictated by the institutional nature of planning policies, which tend to show very little variation within countries and over time, and are thus often indistinguishable from other country characteristics.

In this paper, I analyze the effects of planning regulations on independent retailers in the United Kingdom exploiting a recent reform, which induced significant heterogeneity in the entry constraints faced by large retail stores both over time and across geographies. The reform was introduced in 1996 with the explicit aim to protect "town center vitality" from the alleged draining effects of large out-of-town retail stores. The new planning guidelines raised the entry constraints on stores in edge-of-center or out-of-center locations not already included in local development plans, and on all retail developments above 2,500 square meters. Crucially, the implementation of the new planning rules was left to the judgment of Local Authorities, which represent the lowest level of local government in the U.K.. This setting generated a great deal of heterogeneity in the

${ }^{3}$ Bertrand and Kramarz (2002) and Viviano (2008) analyze the employment effects of planning regulations in the French and Italian sectors, but do not focus explicitly on the interactions between large stores and independent retailers. Haltiwanger, Jarmin, and Krizan (2010) estimate the effects of big-box entry on mom-and-pop stores in the Washington D.C. area, but do not consider the role of planning regulations. See Section II for further details on the existing literature. 
restrictiveness of the planning policy both over time and across geographies, thus offering the unique opportunity to study the impact of the new entry restrictions within a single country.

Using detailed planning data across 303 English Local Authorities between 1993 and 2003, I show that the reform coincided with a significant decline in retail planning grants over time, and substantial heterogeneity in the number of grants across Local Authorities. While variation in grants can be partly traced back to observable differences in demand across Local Authorities, it also appears to vary according to local political factors. In particular, Local Authorities with a greater fraction of Conservative councilors tended to approve fewer grants, even when a rich set of time varying controls and Local Authority fixed effects is controlled for. This finding reflects the political weight of middle-class homeowners and small retailers in the Conservative party, which were more likely to be concerned about the possible competitive generated by big boxes, as well as about the downgrading effect they were feared to have on property values due to increased congestion and impact on environmental décor.

To evaluate the employment effects of the planning reforms, I match the number of planning grants given in the Local Authority with yearly employment data on retail establishments drawn from previously untapped census data on between 1998 and 2004. The main finding of the paper is that independent retailers were actually harmed by the creation of entry barriers against large shops. Instead of simply reducing the number of new large stores entering a market, entry regulations created the incentive for large retail chains to invest in smaller and more centrally located formats, which competed more directly with independents and accelerated their decline. The analysis shows that a one standard deviation decrease in the number of planning grants given in a Local Authority coincided with a $1.7 \%$ increase in the employment growth of small chain formats, and a $0.48 \%$ decrease in the employment growth of independent retailers. Furthermore, 
the increase in the employment growth of small chain formats is directly and negatively correlated with the employment growth of independent retailers.

A possible concern with these results is that the number of granted applications may proxy for unobserved factors correlated with retail employment growth, but different from the restrictiveness of the regulatory policy. I address these concerns in three steps. First, I use a placebo experiment to show that planning grants have no correlation with the employment growth of the manufacturing sector, and they therefore do not appear to proxy for unobserved factors correlated with general employment growth at the Local Authority level. Second, I show that the results are robust to richer empirical specifications, including a larger set of demand controls and Local Authority specific employment trends. Third, I analyze the employment effects of the planning grants with an instrumental variable (IV) approach, which isolates the variation in planning grants determined by entry regulation from that determined by local demand conditions. The IV strategy is similar to the one adopted by Bertrand and Kramarz (2002), in which the instruments exploit the fact that the concession of planning grants was managed by elected politicians, whose decisions were influenced by the electorate attitude towards large stores rather than possible unobserved shocks to retail employment. Reassuringly, the IV results confirm the relationships described above. The IV results on the employment effects of planning grants on small formats and independents are largely robust to a number of checks, including the use of alternative functional forms in the implementation of the IV strategy, the use of alternative timing assumption for the planning restrictions, the inclusion of a richer set of time varying control variables and the use of national instead of local election results as instruments.

The economic magnitude of the estimates is far from negligible. According to the baseline OLS and IV estimates, respectively, the planning reform accounts for between $4 \%$ to up to $22 \%$ of 
the increase in the employment of small formats opened by large chains, and $6 \%$ up to $26 \%$ of the decline in employment experienced by independent retailers between 1998 and 2004. Finally, the results suggest that the effects of planning on both small formats and independent stores operate primarily via the extensive margin, i.e. entry of small chain formats and exit of independent stores.

Overall, these findings suggest that the effects of planning regulations interact with the store strategies of large retail chains. In this setting, restricting the entry of large stores does not necessarily lead to a world with fewer stores, but one with different stores, with uncertain competitive effects on independent retailers.

The remainder of the paper is organized as follows. Section II provides an overview of the existing literature. Section III describes the basic features of the U.K. planning regime and the 1996 reform. Section IV shows basic summary statistics data on the industry and its evolution over time, including the shift made by retail chains towards small formats. Section V focuses on the econometric modeling and the identification strategy and Section VI presents the main results. Section VII concludes.

\section{Literature Review}

The paper is related to several strands of the literature. The employment effects of planning regulations were first investigated by Bertrand and Kramarz (2002). Exploiting cross sectional and time series variation in the implementation of the French planning policy, they find that a more lenient approach towards planning regulation is associated with significant retail employment growth. Similar to this paper, Bertrand and Kramarz corroborate the OLS result with IV estimates, using instruments based on local political preferences. This paper differs from Bertrand and Kramarz in that it adopts the same identification strategy to investigate in much more detail the 
mechanisms though which planning affects retail employment, and in particular the reaction of large retail chains to the new entry barriers. Viviano (2008) investigates the employment effects a recent reform, which introduced significant heterogeneity in planning restrictiveness across Italian regions. She uses a difference in differences approach to show that entry regulations have a negative and sizeable impact on employment growth, including small retail trade shops, but the analysis does not explore the sources of employment growth, or the mechanism behind the employment effects of planning policies. $^{4}$

Although this paper provides the first analysis of the effects of the recent U.K. planning changes on independent retailers, other studies have looked at their impact on different economic outcomes. Smith (2006) combines a random households survey with a dataset of store characteristics to investigate the effect of the planning reform on consumer and producer welfare. He concludes that the U.K. planning reforms imposed suboptimal store characteristics on both consumers and firms, forcing them to focus on small instead of middle-sized stores, which is entirely consistent with some of the findings presented in this paper. More directly related to this paper is Griffith and Harmgart (2008), investigating the effect of planning regulation on the U.K. market structure, namely on the changes in the composition of the U.K. retail industry between large out-of-town and small chain stores. Using a structural model of retail competition, they show

${ }^{4}$ Using similar data, Schivardi and Viviano (2011) show that entry regulations across Italian regions are also associated with higher profit margins and lower productivity of incumbent firms. Furthermore, they also show a negative effect of planning regulations on ICT investments and food prices. Unfortunately this analysis is not replicable in this context due to the absence of productivity data for the vast majority of retail firms included in the U.K. Census. 
that planning regulation has a statistically significant impact on the number of firms operating in a region, although the effects are halved once observable differences across Local Authorities in population density, employment, and distance from town centers are taken into account. Reassuringly, the main results and the economic magnitudes presented in the current paper are robust to the inclusion of these additional fixed and time varying controls in the regressions. Furthermore, while this paper takes into explicit consideration potential biases arising from the endogeneity issues surrounding the entry of large supermarkets, these are largely ignored in Griffith and Harmgart. Cheshire and Hilber (2008) look at the economic impact of planning constraints, which apply specifically to office spaces. Using a method proposed by Glaeser, Gyourko, and Saks (2005), they provide evidence for the existence of a "regulatory tax" on the rental price of office spaces, which they quantify to be an "order of magnitude greater than the peak observed in the most restricted sector, in the most restricted markets in the United States (Cheshire and Hilber 2008, F215).” The Cheshire and Hilber study also highlights the political economy determinants of planning policy, inasmuch as business control makes a significant difference to the tightness of regulatory constraints on office building. More recently, Cheshire, Hilber, and Kaplanis (2011) adapt the same identification strategy proposed in this paper to estimate the effects of planning regulation on retail productivity. Their results - based on a small cross sectional dataset of English chain stores - show the presence of significant and negative effects of regulation on firm productivity, due to the emergence of smaller retail formats and the suboptimality of retail locations induced by the regulatory restrictions.

Finally, this paper is related to the growing literature looking at the competitive effects of Wal-Mart and K-Mart stores on local competitors across U.S. counties. The studies conducted so far using county level data have produced mixed results. Basker (2005), for example, finds that 
Wal-Mart is associated with an overall positive effect on retail employment immediately after entry, which is halved after five years, when some small and medium retail establishments close. Using a different IV approach and Wal-Mart entry data, Neumark, Zhang, and Ciccarella (2008) find a negative effect of Wal-Mart entry $(-2 \%$ to $-4 \%)$ on total retail employment and on payrolls per worker (-3.5\%). Jia (2008) looks at the effect of Wal-Mart and Kmart entry on small discount retailers using a fully structural approach, and finds that Wal-Mart expansion from the late 1980s to the late 1990s explains about fifty to seventy percent of the net negative change in the number of small discount retailers. More recently, these initial findings have been refined through the use of more disaggregated data. Haltiwanger, Jarmin, and Krizan (2010), for example, use a very rich dataset providing location, product, and employment information for the population of retail stores active in the Washington D.C. Metropolitan area to show that the impact of big-box entry on other retailers (including mom-and-pop stores) is characterized by considerable heterogeneity. More specifically, negative employment effects can be found only for stores that operate in the immediate area and same detailed industry of the new big-box. Ellickson and Grieco (2011) use a full census of the supermarket industry to investigate the impact of Wal-Mart entry in the grocery sector and show that the effects on competitors are highly localized (within a three mile radius of distance from the location of Wal-Mart entry). With respect to this literature, this paper provides the first explicit estimates of the big-box effect in a European context. This is of interest, as the interactions between big-boxes and independent stores might be differ in a context—such as the one prevalent in Europe — of higher agglomeration and density. 


\section{Planning Reforms in the United Kingdom}

\section{III.A. The U.K. Planning Policy: Overview}

Similarly to other countries, in the United Kingdom, new developments need to comply with environmental and urban design considerations, which are described in general planning guidelines.

While the broad characteristics of the planning regime remained fairly constant over time, the attitude vis-à-vis big-box stores significantly changed towards the first half of the 1990s. Until the late 1980s, the liberalizing efforts of Mrs. Thatcher's government determined a laissez faire approach towards large retail stores, which coincided with a strong wave of retail decentralization and a significant increase in big-box openings. However, in the early 1990s planning policies registered a drastic change. The main concern driving these changes was that large and peripheral retail stores were draining activities away from town centers, and allegedly causing their socioeconomic decline. Therefore, in order to "sustain and enhance the vitality and viability of town centers," new entry regulations were introduced in 1993 and, more significantly, in 1996.

The new planning guidelines imposed specific entry constraints on stores in an edge-ofcenter or out-of-center locations not already included in local development plans. The new regulations required new out-of-town developments to comply with the "sequential test" (i.e. the proof that no other central location was suitable for the new shop) and the "test of need" (i.e. the proof that the new development was "needed" to meet local demand conditions). ${ }^{5}$ Furthermore, the

${ }^{5}$ The Competition Commission (2000) interpreted the sequential test and the test of need in the following way: "Developers proposing new supermarkets outside town, district, or local centers, 
planning reform required the admissibility of these new developments had to be judged upon their impact on centers within their catchment area, including their effects on economic growth, employment, and the existence of local shops and services. ${ }^{6}$ These criteria had to be applied to all major retail developments, defined as being above 1,000 square meters. ${ }^{7}$ Since large retail stores are generally located out-of-town, the new guidelines implicitly introduced additional costs for all large supermarkets. Taken together, with these changes "guidance evolved from a position in

where the proposal is not in accordance with an up-to-date development plan strategy that is consistent with national planning guidance, must demonstrate that: (a) there is a 'need' for the retail floor space proposed; and (b) there are no more central sites that are suitable or available for developing such a store, after having been flexible about format, scale, design, and amount of car parking required in a genuine attempt to fit into the center (p. 269)."

${ }^{6}$ The emphasis on employment and local shops and services was explicitly introduced in a clarification of the planning policy issued in 2005. "Local authorities should, where appropriate, seek to protect existing facilities which provide for people's day-to-day needs and seek to remedy deficiencies in local shopping and other facilities to help address social exclusion" (ODPM 2005, p. 19).

${ }^{7}$ The 1,000 square meters threshold is a lower bound for the concept of "large store" by industry standards, For example, Tesco — the leading supermarket chain in the United Kingdom—classifies large and medium stores as follows: Hypermarkets, 64,000 (5,946 square meters); Superstores, 31,000 square feet (2,880 square meters); Metro, 11,800 square feet (1,096 square meters). Small convenience stores (Express) are on average 2,100 square feet (195 square meters). See www.tescocorporate.com/images/Tesco\%20PLC\%2030-mar-05.pdf (accessed August 2008). 
which out-of-center development was acceptable to one in which it should be seen as a last resort" (Competition Commission 2000, p. 266).

The reform generated a significant shock to the planning system, adding non-trivial monetary and non-monetary costs to the application process. For example, the Barker Review (2006) reports that applications for large retail stores cost an average of $£ 70,000$, and in a recent inquiry conducted on the U.K. Grocery market, the Competition Commission (2000) reports an average cost of $£ 50,000$, with application delays for the major supermarkets varying from a minimum of 4 months to a maximum of 24 months.

Unsurprisingly, the reforms coincided with a stark reduction in the number of planning applications submitted for the opening of large retail stores. A study commissioned by the U.K. Government (ODPM 2004) documents that the number of planning applications for major retail developments experienced a drastic fall in the immediate aftermath of the 1996 planning reform, from an average of approximately 1,400 annual grants between 1990 and 1995, to an average of 1,160 grants between 1996 and 2001, with an overall 16\% decline in the number of grants between the two sub-periods.

While the 1996 reform created a discontinuity in the restrictiveness of the entry regulations over time, it also generated cross sectional heterogeneity by assigning the responsibility for the implementation of the new central guidelines to Local Authorities. Local Authorities represent the lowest level of local government in the United Kingdom, and their boundaries generally coincide with well-defined socio-geographic entities (a town, or a city and its surroundings), with the major exception of London, which is subdivided into 32 Boroughs. ${ }^{8}$ With the new regime, Local

${ }^{8}$ In some areas, there is a county council responsible for some services within a county, with 
Authorities became responsible for the determination of planning applications in the area under their jurisdiction (an activity defined as development control), within the national guidelines set by the central government planning policies and regional or local development plans. While some minor forms of development would not need planning permission, Local Authorities became responsible for determining approval of major applications. The decision had to be based on widespread consultation with interested parties, including those likely affected by the development in the local areas. Typically, the application for a grant would also be preceded by significant preapplication discussions between developers and local authorities, as well as local communities. ${ }^{9}$ Overall, the reforms thus made the number of applications granted by Local Authorities a function of both local demand conditions, which generated the number of potential entrants in the market, and the activity of locally elected councilors and planning officials, which determined the extent to which central entry regulations were binding in the Local Authority and, therefore, the selection of the actual entrants. I analyze the actual micro level variation in planning outcomes both over time and across geographies in the next section.

several district councils responsible for other services, including planning. The units analysed in this paper are thus district councils. See Appendix for more details on the structure of the British Local Government system.

9 The Secretary of State retained the power to decide over appeals presented with regards to planning applications refused or not determined within a given period of time, but in 2004/2005 this involved only about $3 \%$ of all planning applications. The Secretary of State also had the power to also "call-in" particularly controversial applications. In 2005/2006 about 50 call-ins decisions were issued. More details on the planning system can be found in Appendix. 
III.B. The UK Planning Policy: Micro Level Analysis

\section{Planning Data}

To analyze the implementation of the regulatory guidelines at the local level, I use official planning data drawn from the applications database maintained by the Office of the Deputy Prime Minister (ODPM) - the institution in charge of overseeing planning matters in England until $2006 .{ }^{10}$ The ODPM provided access to the list of all retail applications ${ }^{11}$ processed between 1993 and 2003, classified by type of development, relevant Local Authority, and year. The planning application data employed in the analysis refers to all "Major Developments", which include all large retail sites above 1,000 square meters. Unfortunately, the ODPM data does not provide the exact location of the development within a Local Authority, or the brand name of the applicant. This lack of information constraints the empirical analysis to Local Authority aggregates, and requires the assumption that Local Authorities behave as fairly independent markets. ${ }^{12}$

${ }^{10}$ Planning data for Scotland and Wales was not available for analysis. The ODPM was rebranded as the "Department for Communities and Local Government" in 2006, when the Deputy Prime Minister became a minister without portfolio and his office had purely secretarial functions.

${ }^{11}$ The data refers to the use classes A1 (Shops: including grocery shops, Shops, post offices, travel agents, hairdressers, funeral directors, internet cafés, dry cleaners) and A3 (Restaurants and cafés: including use for the sale of food and drink for consumption on the premises).

${ }^{12}$ For this reason, Local Authorities for which the independence assumption is obviously inappropriate are excluded from the analysis. These are the 32 small and adjacent Local 
In what follows, planning restrictiveness is inferred from the number of planning applications for major retail developments granted by the Local Authority in any given year after the planning reform was introduced. Using the number of grants instead of the share of applications granted is justified by the documented importance of pre-application discussions between Local Authorities and potential applicants (Competition Commission 2000). This implied that the share of applications granted was actually very high (on average $80 \%$ of the submitted planning applications were granted) in the period under consideration. In this context, using the share of applications granted may potentially underestimate the stringency of the planning regime.

The main summary statistics describing the planning data at the Local Authority level, together with basic information on the Local Authorities included in this analysis, are reported in Table 1. On average, over the period 1993-2003 Local Authorities approved only 2.6 large stores openings per year (or 0.022 applications per ' 000 people), with $22 \%$ of the sample granting zero applications in a given year. Consistently with the discussion presented in Section III.A, the number of planning grants experienced a sharp decline immediately after the introduction of the 1996 planning reform. Figure 1 -which plots the evolution of retail planning grants over time using Local Authority level data — reveals that this decline cannot be attributed to a declining trend pre-dating the 1996 reform.

Authorities (Boroughs) representing London, and Local Authorities with a population of more than 400,000 people, whose complexity is not likely to be captured by the aggregated data. This corresponds to the exclusion of all Local Authorities in the $99^{\text {th }}$ percentile of the distribution of population across Local Authorities (Birmingham, Bradford, Leeds, Liverpool, Manchester, and Sheffield). 
The data also shows considerable variation in planning activity across Local Authorities. Figure 2 maps all Local Authorities with available data according to the average number of major planning applications they granted between 1993 and 2003, with darker colors denoting areas with more intense activity. The two subsections below explore two types of factors driving the cross sectional heterogeneity in planning grants: demand drivers and political influence.

\section{Demand Drivers}

Table 2 analyzes the role of demand drivers in accounting for the variation of retail planning grants across Local Authorities, looking at the correlation between planning grants and basic demographic and socio-economic variables across the Local Authorities between 1993 and 2004. ${ }^{13}$ This reveals that major retail grants are more likely in more populated areas (column 1), and in Local Authorities with a higher fraction of urban areas (column 2). In terms of demographics and income differences, Local Authorities with a younger population (expressed as the fraction of people below 15 years old, column 3), lower average income (column 4, not significant) and a lower percentage of college graduates (column 5), are characterized by a higher number of planning grants. When all the demographic and socio-economic variables are included in the regressions, they all retain similar magnitudes and significance levels (column 6), with the exception of the variable describing the fraction of urban areas within the Local Authority, which turns negative and insignificant.

These patterns are compatible with the notion that large stores - which focus their activity

${ }^{13}$ All the regressions reported in Table 2 include year dummies to control for countrywide shocks, and standard errors are clustered at the Local Authority level. 
on the convenience of their offer - tend to target price sensitive consumers. On the other hand, they could also reflect the fact that poorer Local Authorities might be more willing to accept large retail developments for regeneration purposes. ${ }^{14}$ When included together (as in column 6), these controls explain $17 \%$ of the observed variance in planning grants, against the $0.07 \%$ explained by year dummies alone, while Local Authority fixed effects and time dummies account for $48 \%$ of grants' variance.

\section{Political Influence}

As discussed above, the 1993 and 1996 reforms delegated to locally elected councilors the implementation of the entry regulations, thus generating a potentially important link between political power in the Local Authority and planning grants.

In order to analyze the importance of political considerations in the implementation of the regulatory guidelines, I focus in particular on the relationship between the share of seats assigned to Conservative councilors and the number of planning grants conceded at the Local Authority level. More than any other party in the United Kingdom, Conservatives have traditionally been associated with a strong opposition towards big-boxes, also defined as Nimby-ism (Not in My Backyard). ${ }^{15}$ This opposition finds its roots primarily in the political weight of middle-class

${ }^{14}$ The option of using planning as a regeneration tool was explicitly stated in the 1996 national planning guidelines (PPG6 1996).

15 This view is broadly confirmed by the results of a recent survey commissioned by the Saint Consulting Group (a private group focusing on planning issues). The survey shows that the majority of people opposing new developments in their local areas voted Conservative. Moreover, 
homeowners and small retailers in the Conservative party, which were more likely to be concerned about the possible competitive generated by big boxes, ${ }^{16}$ as well as about the downgrading effect they were feared to have on property values due to increased congestion and impact on environmental décor. Others (Greed, 2000) mention the importance of more opportunistic considerations for the Nimby attitude of Conservative politicians in the early 1990s, such as the need to capture the Green vote (at the time $15 \%$ of voters were voting Green and this was seen as a serious threat to retaining a Conservative majority). ${ }^{17}$

The relevance of the Conservative party shares for the concession of retail planning grants can be empirically analyzed combining ODPM planning data with the British Local Election Database (BLED) ${ }^{18}$ which provides candidate-level information on the outcomes of all local

Conservative voters tended to oppose convenience food stores and supermarkets more than any other party (Saint Consulting 2009).

${ }^{16}$ According to the British Election Study, in the 2001 general election small business owners (including retailers) were three times more likely to vote Conservative than any of the two other major parties. Small business owners accounted for $5.85 \%$ of all Conservative votes, against the $1.84 \%$ of Labor and $1.91 \%$ of Liberal Democrat votes. The British Election Study follows the "Goldthorpe-Heath" classification, which provides a total of eleven different socio-economic cells. The cell "Small proprietors, with Employment" is the one including independent retailers and where the difference between the Conservatives and the other parties is starkest.

${ }^{17}$ Bertrand and Kramarz (2002) discuss the support for entry regulations by Right wing parties in France.

${ }^{18}$ The BLED data is described in the Appendix. 
elections that have taken place in the United Kingdom between the late $19^{\text {th }}$ century and 2003. For the purposes of this paper, the data has been aggregated at the Local Authority level, and the sample constrained to the 303 English Local Authorities that are at the base of the results presented in the econometric section.

Table 3 explores the relationship between Conservative and retail planning in the time period 1993-2003 using Local Authority level aggregates. Column 1 shows the correlation between the number of major retail applications granted by the Local Authority and a dummy identifying Conservatives absolute majorities in the council (the regression controls for year dummies). The correlation is very strong, with a coefficient of -0.669 , significant at the $1 \%$ level. Further analysis shows that even the relative majority dummy and the share of seats won by Conservatives in the elections are associated with more restrictive planning outcomes (columns 2 and 3). ${ }^{19}$

The negative correlation between planning grants and Conservative power could be driven by specific demand characteristics of the Conservative electorate, such as differences in income or skills. Therefore, column 4 includes the demand variables that were found to be significantly associated with retail grants in Table $2 .{ }^{20}$ Including these extra controls lowers the point estimate

${ }^{19}$ The omitted category in columns (3)-(6) is the share of seats going to all other parties.

${ }^{20}$ These are the log of population (measured in 2001), the log of median hourly wages, the fraction of urban and village areas, the percentage of people below 15 years, and the percentage of people with a college degree (measured in 2001) in the Local Authority. Conservative majorities are more likely in areas with higher median hourly wages and a higher percentage of college graduates, while they are less likely in more populated and urban areas. 
of the Conservative share, although the variable remains significant at the $1 \%$ level. A further concern is that the correlation between planning outcomes and Conservatives could be driven by unobserved trends at the Local Authority level. Columns 5 and 6 repeat the estimation including, respectively, Local Authority fixed effects, and Local Authority trends. In both cases the point estimate of the variable measuring Conservative shares is lower, but still significant at the $10 \%$ level even in this demanding specification.

\section{Summary}

In summary, the data shows considerable variation in planning grants both over time and across Local Authorities in the post-reform years. While demand drivers are certainly an important source of cross sectional heterogeneity in grants, there is also evidence that political considerations - and in particular the political affiliation of the councilors in charge of implementing the planning policy - affected the number of planning grants, and hence the entry of large retail stores.

Section V exploits the local variation in planning grants and its political determinants to explicitly estimate the employment effects of planning regulation in the retail sector, and discusses in detail the identification challenges associated with this exercise. In the next section I provide a brief overview of the employment data and the evolution of the retail sector in the post reform period.

\section{Retail Employment in the Post Reform Period}

To evaluate the effects of planning regulation on retail employment, I match the planning grants data described in Section III with employment data aggregated at the Local Authority level. In this section I describe the data sources and definitions used in the analysis and provide a basic 
overview of the industry and the changes experienced in the post reform period.

\section{IV.A Sources and Definitions}

The employment data is drawn from previously untapped data files of the U.K. Census (Interdepartmental Business Register, IDBR). ${ }^{21}$ The IDBR is the base of most micro level surveys run in the United Kingdom (see the Appendix for details). The files provide information on the exact location and employment of the population of every retail stores active in the United Kingdom, for each year between 1998 and $2004 .^{22}$

I focus the analysis on all stores classified under the industry code "Non specialized retail" (SIC 521), which includes stores selling non-specialised food and/or beverages, newsagents, and tobacconists. This sector alone accounts for $60 \%$ of total retail employment in the United Kingdom, and the largest share of single-establishment firms. This is also the sector that was more

${ }^{21}$ This is a major difference with respect to Bertrand and Kramarz (2002), where retail region-time specific employment aggregates were drawn from the French Labour Force Survey. Using store level data is clearly needed in this context, since the focus is on specific type of retailers rather the than broad employment aggregates.

${ }^{22}$ The store level data also provides zip codes, which can be matched to Cartesian coordinates and potentially identify the precise location of the store relative to the town center. The main challenge in pursuing this type of analysis is that the precise definition of U.K. town centers is still in its experimental phase, and limited to few geographic locations. See http://www.casa.ucl.ac.uk/projects/projectDetail.asp?ID=23 (accessed September 2011) for more details. 
likely to expand via large retail formats in the pre-regulation period (Haskel and Sadun 2011), and thus more likely to be affected by the entry regulations described in Section III.

In the census data every store is associated with a firm level identifier, which enables me to distinguish between single and multi establishment firms, and to calculate total firm employment using the sum of employment across all stores. This richness of information is especially important in the context of this paper, for two reasons. First, this allows me to isolate the effects of planning on independent stores, i.e. single establishment firms. Second, it also gives me the opportunity to evaluate the effects of planning on the other firms competing with independents, and in particular on the largest U.K. retail chains, which were much more exposed to the new planning restrictions given their reliance on large stores (Haskel and Sadun, 2011). To explicitly consider the heterogeneity of the effect of planning on different retail firms, in what follows I thus distinguish between three firm types: large retail chains (multi establishment firms with more than 10,000 employees), small retail chains (multi establishment firms with fewer than 10,000 employees) and independent retailers (single establishment retail firms). ${ }^{23}$

${ }^{23}$ The 10,000 employees cutoff was chosen to isolate the largest retail firms with sufficient precision, without infringing the Census non-disclosure requirements. There are in total 69 firms in the industry 521 that satisfy this requirement. Of these, only 33 have both large and small retail formats (as defined using the 28 employees per store cutoff used to identify small formats). Tables A2 and A3 in Appendix show that the main results discussed in the paper are robust to alternative classification methods. 


\section{IV.B Changes in Store Formats and Employment in the Post-Reform Period}

To give some sense of the industry structure and the changes experienced in the sector during the period under consideration, Table 4 shows basic summary statistics for firms and store employment for two time periods, 1998, the first year in which the census data is available, and the last available post reform year, 2004. The left side of the table focuses on number of employees and stores for each type of firms in the two time periods, while the right side shows the size (in terms of employees) of stores belonging to these firms at different points of the store distribution.

Large retail chains account for the vast majority of employment in the sector (above $70 \%$ in both 1998 and 2004), followed by small chains (15\% on average between the two time periods) and independents (10\%). Large chains are also more likely to open larger stores (median store size employment in 1998 was 33 for large retailers, vs. 17 for small chains and 2 for independent retailers), and thus account for a much smaller fraction of stores (15\%, vs. $17 \%$ for small chains ad $65 \%$ for independents).

The data points to the remarkable heterogeneity in the growth of employment across the three types of retail firms in the post reform period. Large retail chains experienced sustained growth in employment (22\%) between 1998 and 2004, while small retail chains and independents declined sharply (-13.5\% and $-7.3 \%$ respectively). Interestingly, however, the growth of large retail chains coincided with a dramatic decrease in the size of their stores. This is presented on the right side of Panel A, which shows a sharp decline in the size of the stores belonging to these firms (measured in terms of store level employees) at the $25^{\text {th }}, 50^{\text {th }}$ and $75^{\text {th }}$ percentiles of the store distribution. ${ }^{24}$ The shift of U.K. retail chains toward smaller formats is in contrast with the relative

${ }^{24}$ In line with the results emerging form the census data, Griffith and Harmgart (2008) show that 
stability in store size of small retail chains and independents (Panel B and C). This is also in clear contrast with the retail chains development in other countries. For example, over the same time period the average store size of national retail chains in the United States-where superstore entry is largely unregulated - increased from 142 to 152 employees (Haskel, Jarmin, Motohashi, and Sadun 2007).

The shift towards small formats is an important factor to take into account when evaluating the employment effect of planning regulations on independent retailers since - while standard big boxes would be typically located in out of town locations - smaller store formats were much more centrally placed and targeted towards occasional urban shoppers (Griffith and Harmgarth, 2008), and thus much closer to the activity of independent retailers. Table 5 presents some data to illustrate this point. The table is based on the population of stores belonging to retail chains with more than 10,000 employees. First, I compute for each store a measure of the number of other retail stores active in the same postcode in the 1998-2004 time period, distinguishing between stores belonging to retail chains, and stores belonging to independent retailers. Second, I regress this variable on a dummy taking value one if the store is a "small format", i.e. if the average employment between 1998 and 2004 is equal or lower than 28 full time employees, which is the median number of employees of store belonging to large retail chains at the end of $2004 .^{25}$ The

the number of small convenience stores opened by the top four U.K. retail chains grew exponentially between 1997 and 2002, while the number of large supermarkets remained constant or declined over the same time period.

${ }^{25}$ Appendix Table A2 shows that results are similar using other classification methods to define small formats. 
regression includes Local Authority fixed effects and the errors are clustered at the postcode level. This analysis shows that, whereas small formats are much less likely to have stores belonging to other retail chains in their vicinity (column 1, -1.04 stores, significant at the $1 \%$ level), they are much more likely to be close to independent stores (column 2, +0.38 stores, significant at the $1 \%$ level). ${ }^{26}$

Overall, the data suggest that the post reform period coincided with a significant change in the store strategy of large retail chains, namely the movement towards smaller and more centrally located stores, and with a sustained decline in the employment of independent stores. In the next section I will investigate the extent to which the planning reforms can account for these changes using detailed micro level data.

\section{Modeling the Impact of Planning on Retail Employment}

The stylized facts shown in the previous section beg a number of questions. First, did planning cause the significant increase in small formats opened by the large U.K. retail chains? Second, how did the reduction in the number of large stores opened and the growth of smaller formats end up affecting independent retailers?

As discussed in Section III, the U.K. reforms provide a unique setting to empirically investigate these questions, exploiting variation in planning over time and across different Local

${ }^{26}$ The results are similar if instead of using the absolute number of independent stores in the postcode I take as dependent variable the share of independent stores in the postcode. The coefficient on the small format dummy in the same specification is 0.1038 , significant at the $1 \%$ level. 
Authorities. I first describe the basic econometric set-up, and then discuss identification challenges and possible ways to address them. Table A.1 in the Appendix provides the basic summary statistics for the variables included in the regressions.

\section{V.A Basic Econometric Model: From Big Boxes to Planning Grants}

I start from a primitive econometric model, where retail employment is a function of the number of large retail stores_-"big-boxes"-active in the Local Authority:

$$
E m p_{i j t}=\theta B B_{j t}+\gamma X_{j t}+\beta_{t}+\alpha_{j}+\mu_{j t}
$$

Since the implementation of the regulatory guidelines vary at the Local Authority level, I first assign each retail store to a Local Authority based on a five digits postcode identifier, and then compute employment aggregates at the Local Authority level, i.e. Emp $p_{i j t}$ is the natural logarithm of the sum of employment of all stores belonging to retail firm type $i$, in Local Authority $j$ at time $t$. $B B_{j t}$ is the number of big-boxes operating in Local Authority $\mathrm{j}$ at time $\mathrm{t} ; \beta_{t}$ are year fixed effects

common across all Local Authorities; $X_{j t}$ is a vector of time-varying Local Authority characteristics.

In order to study the impact of regulation on the industry level changes discussed in Table 4, I consider three types of retail firms, each corresponding to a different $i$ : large retail chains (multi establishment firms with at least 10,000 employees); small retail chains (multi establishment firms with less than 10,000 employees); and independent retailers (single establishment retail firms). Furthermore, to investigate the role of regulation in determining the shift towards smaller store formats for retail chains with more of 10,000 employees, I decompose 
the employment growth of these firms between two types of store types: "Small Formats" - i.e. all large chain stores with less than 28 employees - and "Large Formats" - all large chain stores with more than 28 employees. This allows me to directly evaluate whether in areas with more restrictive implementation of the planning reform experienced a more rapid increase of small store formats.

Year dummies are included in all regressions to capture aggregate economic shocks that might affect retail employment. Since Local Authorities have very little discretion in setting their own policy, with the notable exception of planning matters, year dummies should control for most of the other policy changes that might have occurred over the period under study such as, for example, minimum wage policies. ${ }^{27}$ Standard errors are clustered at the Local Authority level to control for autocorrelation patterns of unknown form (Bertrand, Duflo, and Mullainathan 2004). Furthermore, all employment regressions are weighted by the share of population living in the Local Authority to ensure representativeness of the results.

The residual is composed by a constant $\left(\alpha_{j}\right)$ and a time-varying local component $\left(\mu_{j t}\right)$. To control for the $\alpha_{j}$-fixed factors that might affect the level of the retail employment aggregates in the Local Authorities - I apply a first difference transformation to equation (V.1). This leads to the following equation:

$$
\Delta E m p_{i j t}=\theta \Delta B B_{j t}+\gamma \Delta X_{j t}+\Delta \beta_{t}+\Delta \mu_{j t}
$$

${ }^{27}$ The minimum wage was introduced on a national basis in the United Kingdom in 1999. See Draca, Machin, and Van Reenen (2006) for details. 
where $\Delta E m p_{i j t}$ is the logarithmic one year employment growth of firm type $i$ in Local Authority $j$ at time $t$. In each period, the change in the number of big-boxes working in a Local Authority can be expressed in net entry terms, i.e. $\Delta B B_{j t}=B B_{-} e n t r y_{j t}-B B_{-} e x i t_{j t .}$ Under the assumption that big-boxes have negligible exit (i.e. $B B_{-}$exit $t_{j-1} \approx 0$ ) given their high entry costs, ${ }^{28}$ employment growth can be expressed as a function of the number of big-boxes entering the Local Authority:

$$
\Delta E m p_{i j t}=\theta B B \_ \text {entry } y_{j t}+\gamma \Delta X_{j t}+\Delta \beta_{t}+\Delta \mu_{j t}
$$

In what follows, I will assume that the number of big-boxes entering a Local Authority at time $t$ is assumed to be identical to the number of planning applications for large stores granted by the Local Planning Authority some time $s$ before the actual entry of the store. This assumption rests on two specific aspects of the planning regulations discussed in Section III, and namely: a) that the opening of a big-box requires a planning grant; and b) that planning grants are very likely to be transformed into actual stores given the non-trivial monetary and non-monetary costs associated with the planning process. Defining as $s$ the time that is needed to build a big-box from the moment the planning application has been granted, i.e. $B B \_$entry $y_{j t}=$ Grants $_{j t-\mathrm{s}}$.

An important consideration relates to the timing needed for a planning grant to be transformed into an actual store. Since no further licenses are needed once the planning application

${ }^{28}$ This assumption is primarily dictated by the lack of precise exit data on large stores. Table 8 , column 8 includes a robustness check including a proxy for the exit of large retail stores as an additional control in the regression and shows that the result are robust to the inclusion of this control. 
is obtained, $s$ essentially corresponds to a construction lag. ${ }^{29}$ Although the precise delay will vary from case to case, official government reports and the assumptions made by retail developers suggest an average construction delay between one and two years. ${ }^{30}$ In the main specification of the paper $s$ is set to 2 , although several robustness checks are presented to investigate the importance of this assumption.

These steps taken together lead to equation (V.4), which represents the baseline specification used in the paper:

$$
\Delta \operatorname{Emp}_{i j t}=\theta \text { Grants }_{j t-2}+\gamma \Delta X_{j t}+\Delta \beta_{t}+\Delta \mu_{j t}
$$

where the variable Grants $_{j t-2}$ represents the number of major planning grants conceded in the Local Authority in year $t-2$.

Finally, for independent retailers I also directly evaluate the impact of small formats on their employment growth by estimating the following equation:

${ }^{29}$ Bertrand and Kramarz (2002), using a similar methodology for the French retail sector, allow for a four-year period lag between a granted application and an actual entry of a store. In their case, the longer lag is justified by the need to obtain a licence to run the store after the planning application has been granted.

${ }^{30} \mathrm{I}$ include robustness checks to verify the sensitivity of this timing assumption, which is derived from ODPM (2004) and DTI (2004) reports. Similar construction lags have been estimated by the specialist magazine Building, which reports in a cost model dated April 1993 an average construction lag of 40 weeks (Davis Langdon and Everest 1993). 


$$
\Delta E_{\text {indep } j t}=\theta \Delta E_{\text {Emp }} \text { small formats } j t+\gamma \Delta X_{j t}+\Delta \beta_{t}+\Delta \mu_{j t}
$$

where $\Delta E m p_{\text {small formats } j t}$ represents the employment growth of all stores below 28 employees belonging to retail chains with more than 10,000 employees.

\section{V.B Identification}

A major challenge in the estimation of equation (V.4) relates to the endogeneity of planning grants, since the same unobserved time-varying factors that influence retail employment growth are likely to play a significant role in determining the demand for big-boxes opening in a market, and therefore the number of planning applications submitted to the relevant Local Authority. In other words, the $\Delta \mu_{j t}$ might be simultaneously correlated with both planning grants and retail employment.

I address this problem in three ways. First, I use placebo experiments to show that planning grants have no correlation with the employment growth of the manufacturing sector, and therefore do not appear to proxy for unobserved factors correlated with general employment growth at the Local Authority level.

Second, I include controls to account for demand differences across Local Authorities, i.e. population growth, age, skills, income profile, and urban characteristics, which are significantly correlated with the number of planning grants conceded at the Local Authority level in Table 2. ${ }^{31}$

${ }^{31}$ This might be relevant in explaining the employment growth of different types of retailers, as well as the choice among alternative retail formats by large retail chains. For example, Griffith and 
Along similar lines, I also experiment with alternative specifications including Local Authority fixed effects to control for different trends in retail employment at the Local Authority level.

Third, similar to the methodology first proposed by Bertrand and Kramarz (2002), I use the shares of seats won by Conservative councilors in Local Authority elections to instrument for the number of planning grants. This is a valid IV strategy under the assumptions that: a) the planning behavior of local politicians is correlated with their party affiliation; and b) the changes in the political composition of the Local Authorities are exogenous to the $\Delta \mu_{j t}$ shocks affecting retail employment.

The correlation between political affiliation - and namely Conservatives influence - and planning grants was already discussed in Section III.B, where it was shown that Local Authorities with more prominent Conservative presence were less likely to concede planning grants, even conditional of a rich set of demand controls.

With regards to point b), i.e. whether the political composition of the Local Authorities can be treated as exogenous to the unobserved $\Delta \mu_{j t}$ driving the employment growth of independent retailers, the main concern is that the political composition of the local council could be directly determined by the retail employment growth. For example, when independent retailers are in decline (or small formats are on the rise), they might be more inclined to vote Conservatives councilors if they expect them to be more effective in blocking the entry of large stores, creating a correlation between election outcomes and economic conditions.

While this problem cannot be entirely ruled out, the practical relevance of this concern is Harmgart (2008) emphasize the role of demand conditions in driving the increase in small formats by the top UK grocery retailers. 
alleviated by the fact that instrumentation strategy exploits changes in the political composition at the time the grant was given, which is typically some time before the actual entry of the store (in most specifications I assume a 2 year delay), and that therefore, a bias would exist if voters were to base their political preferences on the basis of their expectations of independents employment growth at least two years after the elections. Furthermore, for about half of the Local Authorities in the sample elections were run "by thirds", i.e. they would elect one third of their councilors in each of the three years out of four which were not county election years. This is an additional institutional factor that should in principle reduce the immediate influence of economic considerations on local political representation.

In practice, to show that the results are indeed robust to this issue, I show robustness checks including controls for time varying socioeconomic characteristics of the Local Authorities and the growth of total employment in the Local Authority. I also experiment with an IV strategy where the main instrument is the share of Conservative votes won at national instead of local elections. While this weakens the power of the instrument due to the less frequent political cycle of national elections relative to local elections, it is useful inasmuch national election preferences are less likely to be entirely determined by their influence on retail employment.

Finally, a bias would arise in the IV estimates if councilors could affect the retail sector via alternative channels. However, the power to set and collect a local property tax on non-residential property (known as the U.K. business rate) at the Local Authority level was abolished in 1990, when the central government decided to take this tax setting power away from Local Authorities and to establish the Uniform Business Rate (UBR). ${ }^{32}$ Therefore, planning was effectively the only

${ }^{32}$ The reasons for the introduction of the UBR were essentially political. The Conservative 
area of responsibility of Local Authorities that could affect businesses directly during the sample (Duranton, Gobillon, and Overman 2006), and this leaves little space for alternative policy related channels of influence.

\section{Results}

\section{A. Main results}

Table 6 examines the effects of planning grants on retail employment using the simple OLS specification of equation V.4, including as additional controls a set of year dummies and the basic demand controls analyzed in Table 2 (log of population, percentage of people living in urban areas, percentage of people below 15 years, $\log$ median hourly wages, percentage people with a college degree).

Column 1 starts by looking at the relationship between grants and the employment growth of large retail chains (i.e. those with more than 10,000 employees). Grants are significantly associated with positive total employment growth of these firms (coefficient 0.0029, standard error 0.0009). The relationship, however, is the result of a composition effect between large and small formats, as columns 2 and 3 show: planning grants are associated with the positive and significant employment growth of large formats (coefficient 0.0036, standard error 0.0010), and a significant decline in the employment growth of small formats (coefficient -0.0059 , standard error 0.0022). These results provide prima facie evidence that the decline in the number of planning grants for

government feared that left-wing councils could frustrate its liberalising efforts by raising antibusiness taxes (Cheshire and Hilber 2008). 
large supermarkets coincided with a substitution towards smaller chain stores.

Given these findings, a question of interest is to what extent did the decline in planning grants affect independent retailers? Note that the effect is a priori ambiguous. While on the one hand fewer planning grants might have reduced the competitive pressures faced by independents by slowing down the entry of big boxes (column 2), on the other hand this also seems to have heightened the incentives to open smaller chain formats (column 3), which are geographically closer to independents (Table 5, column 2) and thus potential substitutes. The net effect of planning would then depend on the relative competitive pressure exerted by small formats vs. big formats on independent retailers.

The estimates suggest that reducing the entry of bog boxes negatively affected the employment growth of independent retailers, and that this was directly related to the substitution towards small chain formats. Column 4 shows that an additional planning grant is associated with an increase in independents' employment growth of $0.17 \%$ (standard error 0.0008 ). To verify the direct relationship between small formats and independent retailers, Column 5 shows that a $1 \%$ increase in the employment growth of small chain formats is associated with a $0.0135 \%$ decline in the growth rate of independent retailers, although the coefficient is significant only at the $10 \%$ level (standard error 0.0077). Finally, column 6 shows that the significant correlation between planning grants and employment is confined to large retail chains and independents, but does not extend to retail chains with fewer than 10,000 employees. This is not surprising, since these firms are less likely to both switch from large to small formats (Table 4, Panel B) and to be affected by the competition of small formats given their location (Table 5, column 1). 


\section{VI.B. Robustness on OLS Estimates}

In the simple specification of equation V.4, a possible worry is that the conditional correlations between employment and planning grants may reflect unobservable local demand correlates not captured by the basic set of covariates included in the regression. In this section, I present a set of robustness checks to allay this concern. Before doing so, however, it is worth noting that the unobservable demand factors would have to follow a very specific pattern of correlation with the employment aggregates examined so far: positive association with both big boxes and independent retailers; negative association with small chain formats; and no correlation with small retail chains.

The first check is a placebo test looking at the correlation between planning and the employment growth of the manufacturing sector. This is a way to verify whether planning grants might capture something beyond a local shock to large chains and independents, since manufacturing employment should not be directly affected by retail planning grants. Reassuringly, column 7 of Table 6 shows that planning grants are not significantly correlated with the growth of manufacturing employment (coefficient -0.0008 , standard error 0.0013). ${ }^{33}$

Second, I test the robustness of the results to the inclusion of a richer set of controls for local demand conditions. These checks focus in particular on the correlation between planning

${ }^{33}$ The sample in this specification drops to 1,478 observations due to the limited availability of the specific version of the LFS employment data used to compute total employment in manufacturing at the Local Authority level, which is available only between 1999 and 2003, and for 302 of the 303 Local Authority included in the baseline sample. The correlation between planning grants and independents' employment growth is still positive significant in this smaller sample. 
grants and the employment growth of small retail formats (Table 6, column 3) and independent retailers (Table 6, column 4). The results are shown separately for small retail formats in Table 7, Panel A, and for independents in Table 7, Panel B.

Column 1 in both panels starts by reproducing the baseline results of Table 6 . Column 2 shows the results when the baseline specification is augmented with a richer set of demand and demographic controls beyond the ones already included in the baseline specification. ${ }^{34}$ The coefficient on planning grants remains significant at the 5\% level and similar in terms of magnitudes for both small format and independent retailers. Another concern is that the results could be spuriously driven by unobserved trends in employment levels across Local Authorities correlated with planning grants. Column 3 thus shows the robustness of the results to the inclusion of Local Authority fixed effects: the correlations with planning grants remain positive and of similar magnitude for both small formats and independent retailers even in this demanding specification, although the significance level drops at the $10 \%$ level in both cases.

Although the OLS results are reassuringly stable, they may still potentially suffer from biases due to omitted unobservable variables. Hence, in order to investigate the causality of the

${ }^{34}$ These are the percentage of people working in manufacturing and retail, an interaction term between $\log$ median hourly wage and a dummy equal to unity for any year after 1999 (this is to capture the possible differential effects of the minimum wage introduction), and the log of the total area (in hectares) covered by the Local Authority. All the added regressors are individually insignificant, with the exception of the interaction post $1999 * \log$ median hourly wage, which is negative and significant at the $5 \%$ level for both small formats and independent retailers. 
relationship between planning grants and independents, I turn to the IV strategy described in Section V.C, which instruments the number of planning grants with the share of seats won by Conservative politicians in the Local Authority.

In the first stage regression, the relationship between planning grants and the share of seats won by Conservatives is negative and significant even in the subsample under examination. In a first stage specification where I regress the number of planning grants given at $\mathrm{t}-2$ on the share of Conservative seats in the same time period (including the same set baseline controls of column 1) the coefficient is -1.73 (standard error 0.5413), which implies that a one standard deviation increase in the share of Conservative seats is associated with a 0.36 decrease in the number of planning grants given in the same year. The power of the political instrument is confirmed by the Kleinbergen-Paap F-test, which is beyond the 10 threshold suggested by Stock, Wright, and Yogo (2002) to identify weak instruments problems.

Column 4 shows the reduced form specification where I directly regress employment growth on the share of Conservative seats. For both small formats and independent retailers the relationship is significant and of the expected sign: an increase in the number of Conservative seats is associated with positive employment growth for small formats, and negative employment growth for independents. Finally, Column 5 presents the 2SLS estimates, where the number of planning grants is instrumented with the share of Conservative seats in the Local Authority at time $\mathrm{t}-2$. The 2SLS estimates of the coefficient on planning grants are also supportive of the baseline OLS findings. For small formats, a unit increase in the number of planning grants translates in a $3.55 \%$ reduction in employment growth (significant at the $5 \%$ level), while for independents this 
translates in a $1.19 \%$ increase in employment (significant at the $10 \%$ level). ${ }^{35}$

\section{VI.C. Magnitudes}

The OLS and IV estimates presented in Table 7 provide, respectively, a lower and an upper bound for the effect of an additional planning grant for a major retail development on the employment growth of small formats and independent retailers. In order to evaluate the economic magnitude of these estimates, I look employment growth figures between 1998 and 2004, and see how much of it can be accounted for by the change in the number of planning grants between 1996 and 2002 (where the different time period is to take into account the 2 year delay between obtaining the planning grant and starting the retail activity assumed in the baseline regressions).

Between 1996 and 2002, on average 0.44 fewer planning applications were granted every year, the employment of small formats increased at an average yearly rate of $7 \%$ per annum, and the employment of independent retailers declined at an average yearly rate of $2 \%$ per annum (Table A1). According to the OLS specification with Local Authority fixed effects (Table 7, Panel $\mathrm{B}$, column 3), the decline in planning grants accounted for roughly $4 \%$ of the increase in the employment of small formats $(0.44 * 0.0065$ divided by 0.07$)$, and $6 \%$ of the decline in the employment of independent stores between 1998 and $2004(0.44 * 0.0027$ divided by 0.02$)$. The IV estimates reported in Table 7, Panel B, column 6, suggest a stronger effect. With this specification,

${ }^{35}$ I also investigated the direct relationship between small chain formats and independent retailers instrumenting the growth of small chain formats with the share of conservative seats in the Local Authority. The first stage of this regression is reported in column 4, Table 7. The 2SLS estimate of the small formats coefficient is -0.3345 (standard error 0.2030 ). 
the estimated impact of the decline in planning grants would account for roughly $22 \%$ of the increase in small formats employment $(0.44 * 0.0355$ divided by 0.07$)$, and $26 \%(0.44 * 0.0119$ divided by 0.02) of the decline in the employment of independent stores between 1998 and 2004.

\section{VI.D. Margins of Adjustment}

To further characterize the effect of planning grants on the employment growth of small formats and independents, Table 8 investigates in more detail differences across the employment growth contributions of incumbents, entrants, and exitors. These employment components are computed using the Davis and Haltiwanger (1992) method, which calculates the employment growth rate of any independent store $i$ within each Local Authority $j$ at time $t$ as:

$$
g_{i j t}=\frac{e m p_{i j t}-e m p_{i j t-1}}{x_{i j t}}
$$

where $x_{i j t}=\frac{e m p_{i j t}+e m p_{i j t-1}}{2}$ and $e m p_{j t k}$ is the employment of store $\mathrm{k}$ at time $\mathrm{t}$ in Local Authority $\mathrm{j}$. This growth rate is symmetric about zero, and lies in the closed interval [-2,2], with deaths (births) taking value of -2 (2). By construction, total employment growth rate is the sum of the contributions to employment growth from entrants, exitors, and incumbents (expanding and contracting), as follows:

$$
\Delta D_{j t}=\sum_{\substack{i \in I_{j t} \\ i \in D}}\left(\frac{x_{i j t}}{X_{j t}}\right) g_{i j t}
$$

where $\mathrm{D}=\{$ Entry, Exit, Expanding Incumbents, Contracting Incumbents $\}$ and $X_{j t}$ represents total average employment in Local Authority $j$ at time $t$.

I regress each growth component for each sub-sample against the planning grants variable, 
using the same baseline IV specification of column 6, Table 7. Starting from small formats (Panel A), the estimates suggest that planning primarily affected the entry margin of these stores (coefficient 0.0571 , standard error 0.0264), while the effects on exits, and incumbents' contraction and expansion is much weaker. At the same time, the positive effect of planning grants on independents is mostly accounted for by a reduction of the exit component, while the effects on incumbents and entrants are smaller and non-significant.

Overall, these results suggest that planning had significant and opposite effects on the extensive margin for both small formats and independents, while the effects on incumbents were much milder. These differential effects are consistent with the idea that the heightened regulation on big boxes resulted in the creation of new small formats stores. They also suggest that the positive effect of planning grants on independents was not driven by general positive spillovers created by big-boxes on surrounding stores, which would result in a more general expansion of incumbents and accelerated entry. ${ }^{36}$

\section{VI.E. Robustness of the IV Estimates}

Overall, the IV estimates confirm the result found with the simple OLS, i.e. planning grants are associated with a negative effect on the growth of small chain formats, and with a positive effect on the employment growth of independent retailers. Table 9 presents further robustness checks on the IV results, for both small chain formats and independent retailers (column 1 reports

\footnotetext{
${ }^{36}$ For example, Gould et al. (2005) document that anchor stores in shopping malls generate externalities to other stores by attracting customers to the mall, and that this is reflected in the contracts underwritten by the other tenants.
} 
the baseline specification of Table 7, column 5).

The first set of checks relates to concerns related to the timing assumption adopted to translate planning grants into proxies for the entry of large supermarkets. Column 2 looks at the relationship between independents' growth and the number of planning grants conceded between $\mathrm{t}-1$ and $\mathrm{t}-3$, using as instruments the sum of Conservative share of seats over the same time periods. The coefficient on this entry measure remains positive and significant at the $5 \%$ for small formats and at the $10 \%$ level for independents, albeit substantially smaller in magnitude with respect to the baseline estimates shown in column 1. To test the sensitivity of the results with respect to the assumption that only grants accepted in $t-2$ enter at time $t$, column 3 analyzes the relationship between log employment and the stock of retail major applications granted between 1993 (the first year of the planning data sample) and $t-2$, including in the regression a full set of Local Authorities dummies (the political instruments are built analogously). In this specification the coefficient on planning grants remains positive and significant at the $5 \%$ level for small formats, but falls just below the $10 \%$ significant level for independents (coefficient 0.0045 , standard error 0.0028). Finally, estimating the regression using two years averages to reduce the possible impact of measurement error in both the entry and the employment variables generates very similar estimates to the baseline in terms of both magnitudes and precision for both small formats and independents (column 4).

Second, a potential problem associated with the use of local elections results as instruments for planning is that voting might be endogenously determined by economic conditions in the Local Authority. To address this concern, column 5 reports the 2SLS regression augmenting the specification with a time varying variable capturing the growth of overall employment in the Local Authority. Column 5 shows that this does not affect the magnitude and significance level of the 
baseline estimates. Column 6 addresses the possibility that both political results and retail employment could be affected by the entry of big box stores in neighboring Local Authorities, including as an additional control a variable summing the number of planning grants conceded in all neighboring Local Authorities at $\mathrm{t}-2$. While the inclusion of this variable does not alter the baseline findings, it is interesting to notice that neighboring planning grants are uncorrelated with the growth of small chain formats, and negatively and significantly correlated with the growth of independent retailers. One way to interpret this result is that the competitive effect arising from the entry of big boxes in neighboring Local Authorities is not offset by the decline in the growth of small chain formats, and thus overall planning grants have an negative effect on the employment growth of independents. Column 7 checks the robustness of the results to the assumption implicit in the econometric model that big box stores have infrequent exit events. In order to build a proxy for big box exit, I use the full panel data on the universe of stores classified in sector 521, and build an indicator taking value one for the exit of stores above the employment threshold of 150 employees (this corresponds to all stores beyond the $99^{\text {th }}$ percentile in the distribution of stores belonging to chains with more than 10,000 employees).${ }^{37}$ The inclusion of this variable does not alter the magnitude and significance level of the baseline estimates.

Finally, to address the concern that local election results might be determined by local employment dynamics, I experiment with an IV strategy where the number of planning grants is instrumented with the share of conservative votes in national elections rather than local elections. This reflects the logic that national election preferences are less likely to reflect specific concerns pertaining to local retail employment patterns. The shortcoming of using national rather than

\footnotetext{
${ }^{37}$ This variable has mean .27 , median 0 and standard deviation .59 .
} 
electoral result is the loss of power in the first stage regressions: whereas partial local elections happened almost on an yearly basis in about half of the Local Authorities included in the sample (see the Appendix for details), there were only two general elections in the period under consideration, 1997 and $2001 .^{38}$ The first stage of this regression confirms the presence of a negative relationship between the number of planning grants and the share of votes won by conservatives in the national elections, but the relationship is only significant at the $10 \%$ level (coefficient -3.283 , standard error 1.744), and the F-test is below the Stock and Yogo threshold. With this caveat in mind, using national elections as instruments for planning grants in the second stage generates a coefficient that is almost double of that obtained using local election results as instruments $(0.0729$, standard error 0.0399$)$ for small chains. The coefficient is still positive but about half of the baseline case and below conventional significance levels (coefficient 0.0049, standard error 0.0070) for independent retailers.

\section{Conclusion}

I investigate the employment effects of planning regulations using a recent reform introduced in the United Kingdom, which substantially affected the cost of opening large retail stores. The key results of the paper are as follows. First, regulating the entry of big-boxes triggered a significant change in the store strategy of large U.K. retailers, which substituted large stores with smaller in-town formats. Second, because of this substitution, planning regulation ended up harming independent retailers, by bringing more competition to their closer proximity. According

${ }^{38}$ I interpolate the election results in non-election years in order to include these years in the analysis. 
to the results shown in the paper, the decline in planning grants generated by the regulatory reforms accounted for between $4 \%$ and $22 \%$ of the employment growth experienced by small formats, and $6 \%$ and $26 \%$ of the employment decline experienced by independent retailers over the time period 1998 and 2004.

This paper provides several contributions. First, this is one of rare empirical studies of regulation that can rely on within country and time series variation, which allows identifying the effects of regulatory policies abstracting from countrywide characteristics and concomitant regulations. Second, the paper provides for the first time direct evidence on the effects of planning regulation on firm strategies, and in particular on the choice between different store formats. Third, the paper highlights the importance of carefully considering counterfactual in the design of regulatory policies: restricting the entry of large stores does not necessarily lead to a world with fewer stores, but one with different stores, with uncertain competitive effects on independent retailers. This point is relevant also outside the context of the U.K. economy, and especially in the United States, where prominent chains such as Wal-Mart and Safeway have started to invest in small and urban formats. ${ }^{39}$ Finally, the paper also has implications for the definition employed by

39 Tesco first introduced small chain formats in the United States in 2007 with the "Fresh and Easy" brand. This move was followed by the decision made by Wal-Mart to open its "Marketside" small-format community grocery stores. These formats involve the creation of neighborhood grocery stores primarily in suburban but also in urban neighborhoods. Interestingly, Wal-Mart's decision has been interpreted as a way to win the permission to open in markets that have been traditionally opposed to the typical Wal-Mart big-boxes, such as the Bay Area in California. For a more recent coverage of Wal-Mart decision to enter with smaller urban formats in regulated areas 
regulators in assessing market size and potential competitive effects of mergers between firms operating according to different store formats. For example, the substitutability between large and small chain stores suggested by this paper is at odds with the market definition adopted by the U.K. Competition Commission in several of its retail inquiries over the past ten years. In these reports, the Competition Commission has generally preferred to consider the large and small retail formats as two distinct markets (Competition Commission 2000). This choice has played a crucial role in determining the feasibility of several takeovers of minor retail chains operating small stores by major retail chains operating large retail stores.

There are several issues surrounding these results that are worth exploring further. First, the short run effects of entry regulations may change in the long run, or impact differentially central and peripheral independents. Second, while this paper focuses primarily on employment effects, large retail stores may also have an impact on the type of activity chosen by independents, for example shifting their activity towards a more specialized retail offer. Third, while the simplicity of the reduced form estimates allow for the use of a clean identification strategy, structural models of firm entry and differentiation would allow to estimate with finer precision the complex interaction between regulation, chain stores, and independents suggested in this paper. ${ }^{40}$

such as New York City see Bustillo (2011).

${ }^{40}$ For example, Datta and Sudhir (2010) estimate a structural model using U.S. store and regulation data to illustrate the idea that planning regulation can induce firms to differentiate via the choice of alternative retail formats. Ridley, Sloan, and Song (2010) present a simple extension of the Salop (1979) model to show that an increase in the fraction of zoned areas within a specific market increases competition in non-zoned locations by forcing retailers closer together. 
More generally, structurally identified model would be able to pursue an evaluation of the overall welfare implications of planning policies, which are deliberately absent from this paper but are first order importance for both economists and policy makers. These are clearly important issues to address, which are left for future research. 


\section{References}

Barker, Kate, "Barker Review of Land Use Planning: Final Report-Recommendations," (December 2006). http://www.hmtreasury.gov.uk/media/3/A/barker_finalreport051206.pdf. Accessed August 2008.

Basker, Emek, "Job Creation or Destruction? Labor Market Effects of Wal-Mart Expansion," Review of Economics and Statistics 87:1 (2005), 174-183.

Basker, Emek, Shawn D. Klimek, and Van H. Pham, "Supersize It: The Growth of Retail Chains and the Rise of the 'Big Box' Retail Format," SSRN eLibrary (May 10, 2010). Available at SSRN: http://ssrn.com/abstract=1240860. Accessed August 2010.

Bertrand, Marianne, Esther Duflo, and Sendhil Mullainathan, "How Much Should We Trust Differences-in-Differences Estimates?” The Quarterly Journal of Economics 119:1 (2004), 249-275.

Bertrand, Marianne and Francis Kramarz, “Does Entry Regulation Hinder Job Creation? Evidence from the French Retail Industry," The Quarterly Journal of Economics 117:4 (2002), $1369-1413$.

Bustillo, Miguel, “Wal-Mart Tries to Recapture Mr. Sam's Winning Formula,” Wall Street Journal (Online) (February 22, 2011). http://search.proquest.com/docview/853011421?accountid=11311. Accessed September 2011.

Cheshire, Paul C. and Christian A. L. Hilber, "Office Space Supply Restrictions in Britain: The Political Economy of Market Revenge,”Economic Journal 118:529 (2008), F185-F221.

Cheshire, Paul, Christian A. L. Hilber, and Ioannis Kaplanis, “Our System of Land Use Planning Can Often Have Damaging Impacts on Retail Productivity," British Politics and Policy at 
LSE (Blog Entry) (11 July 2011). http://eprints.lse.ac.uk/38040/. Accessed September 2011.

Competition Commission, "Supermarkets: A Report on the Supply of Groceries from Multiple Stores in the United Kingdom," (October 2000). http://www.competitioncommission.org.uk/rep_pub/reports/2000/446super.htm\#full. Accessed August 2008.

Datta, Sumon and K. Sudhir, "Does Reducing Spatial Differentiation Increase Product Differentiation? Effects of Zoning on Retail Entry and Format Variety," SSRN eLibrary (December 9, 2010). Available at: http://ssrn.com/paper=1722949. Accessed September 2011.

Davis Langdon and Everest, “Cost Model: Supermarkets,” Building (April 1993). http://www.building.co.uk/data/cost-model-supermarkets/1025793.article. Accessed August 2011 .

Davis, Steven J. and John Haltiwanger, "Gross Job Creation, Gross Job Destruction, and Employment Reallocation," The Quarterly Journal of Economics 107:3 (1992), 819-863.

Draca, Mirko, Stephen J. Machin, and John M. Van Reenen, "Minimum Wages and Firm Profitability,” IZA Discussion Paper No. 1913; CEP Discussion Paper No. 715 (January 2006). Available at SSRN: http://ssrn.com/abstract=877892. Accessed September 2011.

DTI Retail Strategy Group, “The Retail Development Process and Land Assembly: Volume 2 Appendices," (February 2004). http://www.dti.gov.uk/files/file17959.pdf. Accessed August 2008.

Duranton, Gilles, Laurent Gobillon, and Henry G. Overman, "Assessing the Effects of Local Taxation Using Microgeographic Data,” CEP Discussion Paper no. 748 (August 2006). Available at: http://ssrn.com/paper=952769. Accessed August 2011. 
Ellickson, Paul B. and Paul L.E. Grieco, "Density Versus Differentiation: The Impact of Wal-Mart on the Grocery Industry," Simon School Working Paper Series no. FR 11-18 April 22, 2011). Available at SSRN: http://ssrn.com/abstract=1819268. Accessed September 2011.

Ennis, Sean, "Land Use Restrictions as Barriers to Entry," OECD Competition Policy Roundtables (2008). http://www.oecd.org/dataoecd/34/37/41763060.pdf. Accessed August 2008.

Foster, Lucia, John Haltiwanger, and C. J. Krizan, "Market Selection, Reallocation, and Restructuring in the U.S. Retail Trade Sector in the 1990s," Review of Economics and Statistics 88:4 (2006), 748-758.

Glaeser, Edward L., Joseph Gyourko, and Raven Saks, "Why Is Manhattan So Expensive? Regulation and the Rise in Housing Prices," The Journal of Law and Economics 48:2 (2005), 331-369.

Gould, Eric D., B. Peter Pashigian, and Canice J. Prendergast, “Contracts, Externalities, and Incentives in Shopping Malls," Review of Economics and Statistics 87:3 (2005), 411-422.

Greed, Clara, Introducing Planning (London; New Brunswick, NJ: Athlone Press, 2000).

Griffith, Rachel and Heike Harmgart, "Supermarkets and Planning Regulation,” CEPR Working Papers no. DP6713 (February 2008).

Haltiwanger, John, Ron Jarmin, and C. J. Krizan, "Mom-and-Pop Meet Big-Box: Complements or Substitutes?" Journal of Urban Economics 67:1 (2010), 116-134.

Haskel, Jonathan, Ron S. Jarmin, Kazuyuki Motohashi, and Raffaella Sadun, "Retail Market Structure and Dynamics: A Three Country Comparison of Japan, the UK and the US," LSE/Ceriba mimeo (July 2007). https://editorialexpress.com/cgibin/conference/download.cgi?db_name=res2008\&paper_id=734. Accessed August 2008. Haskel, Jonathan and Raffaella Sadun, "Regulation and U.K. Retailing Productivity: Evidence 
from Microdata," Economica (2011). http://dx.doi.org/10.1111/j.1468-0335.2011.00903.x. Accessed September 2011.

Holmes, Thomas J, "Bar Codes Lead to Frequent Deliveries and Superstores," The RAND Journal of Economics 32:4 (2001), 708-725.

Jia, Panle, "What Happens When Wal-Mart Comes to Town: An Empirical Analysis of the Discount Retailing Industry,” Econometrica 76:6 (2008), 1263-1316.

McKinsey Global Institute, "Driving Productivity and Growth in the U.K. Economy," (October 1998). http://www.mckinsey.com/mgi/reports/pdfs/ukprod/ukprod.pdf. Accessed August 2008.

Neumark, David, Junfu Zhang, and Stephen Ciccarella, "The Effects of Wal-Mart on Local Labor Markets," Journal of Urban Economics 63:2 (2008), 405-430.

Office of the Deputy Prime Minister (ODPM), "Policy Evaluation of the Effectiveness of PPG6," (January 2004).

http://www.communities.gov.uk/documents/planningandbuilding/pdf/148199.pdf. Accessed August 2008.

Office of the Deputy Prime Minister (ODPM), "Planning Policy Statement 6: Planning for Town Centres (PPS6)," (March 2005).

http://www.communities.gov.uk/documents/planningandbuilding/pdf/147399.pdf. Accessed August 2011.

Pilat, Dirk, "Regulation and Performance in the Distribution Sector," OECD Economics Department Working Papers no. 180 (January 1997). http://dx.doi.org/10.1787/121136556730. Accessed August 2008.

Ridley, David B., Frank A. Sloan, and Yan Song, "Retail Zoning and Competition," (March 12, 
2010). http://faculty.fuqua.duke.edu/ dbr1/research/zoning-competition.pdf. Accessed September 2011.

Saint Consulting, “2009 UK Saint Index—Headline Results,” (2009). http://tscg.biz/the-saintindex/canada-and-uk. Accessed September 2011.

Salop, Steven C., "Monopolistic Competition with Outside Goods," The Bell Journal of Economics 10:1 (1979), 141-156.

Schivardi, Fabiano and Eliana Viviano, "Entry Barriers in Retail Trade," The Economic Journal 121:551 (2011), 145-170.

Smith, Howard, "Store Characteristics in Retail Oligopoly," The RAND Journal of Economics $37: 2$ (2006), 416-430.

Stock, James H., Jonathan H. Wright, and Motohiro Yogo, “A Survey of Weak Instruments and Weak Identification in Generalized Method of Moments," Journal of Business and Economic Statistics 20:4 (2002), 518-529.

Viviano, Eliana, "Entry Regulations and Labour Market Outcomes: Evidence from the Italian Retail Trade Sector," Labour Economics 15:6 (2008), 1200-1222. 


\section{APPENDIX}

\section{The British Local Government}

\section{A. Structure}

The structure of local governments in England has experienced several changes over time. In 1974, a two-tier administrative structure of counties and non-metropolitan districts was set up across the whole of England and Wales, except for the Isles of Scilly, Greater London, and the six metropolitan counties. Council functions were divided according to the level at which they could be practiced most efficiently. In consequence, counties took on functions including education, transport, strategic planning, fire services, consumer protection, refuse disposal, smallholdings, social services, and libraries, whereas the districts (between 4 to 14 within each county area) had responsibility for local planning, housing, local highways, building, environmental health, refuse collection, and cemeteries. Responsibility for recreation and cultural matters was divided between the two tiers. In the major urban areas such as London, West Midlands, Greater Manchester, Merseyside, South Yorkshire, West Yorkshire and Tyne \& Wear a partial reorganization in 1986 created a single tier of councils responsible for all the services listed above. These are called London Borough Councils and Metropolitan District Councils.

In the 1990s, the Central Government's view was that the two-tier model of service provision was inefficient, and that County Councils were too distant from the needs of the population they served. Therefore a Local Government Act in 1992 in England and special laws enacted in 1994 for Scotland and Wales abolished County councils and transferred their functions to district councils, with some of the smaller districts being merged. The newly created single-tier 
councils were called Unitary Authorities, and had responsibility for all areas of local government. Between 1995 and 1998, these were established in a number of areas across the country, especially in medium-sized urban areas, while other areas retained a two-tier structure. Up until 2009, there were 46 Unitary Authorities in England, and 34 shire Counties split into 239 non-Metropolitan Districts, plus the 32 London Boroughs and the other 36 Metropolitan Districts, which retained their own structure.

Councilors represent geographical areas within a Local Authority (Wards) and serve for four years before going up for reelection. In England, London Boroughs elect all their councilors at once, every four years. Metropolitan Authorities elect one third of their councilors in each of the three years out of four which are not county election years. In England until 2009, 18 out of the 46 Unitary Authorities and 88 of the other 239 non-Metropolitan districts elected their local councils "by thirds".

\section{B. Local Planning Responsibilities and the Role of the Center ${ }^{41}$}

The planning system is articulated at the national level through the implementation of central government planning policies; at the regional or local level through development plans; and the site specific level though the determination of planning applications (development control).

England operates under a "plan-led" system, which implies that planning authorities must determine planning applications in accordance with the statutory development plan, unless "material considerations" indicate otherwise. Until 2004 (the last year included in the analysis of

\footnotetext{
${ }^{41}$ This section draws from Chapter 1, Barker Review (2006)
} 
this paper), the plan-making system was based on Regional Planning Guidance (prepared by informal regional bodies and government offices), structure plans (prepared by county councils) and local or unitary plans (prepared by district authorities). The system was replaced with a more centralized approach in 2004.

Development control is the specific task assigned to local planning authorities. This is the process through which planning applications are made for site-specific developments or a material change of use of land or buildings. Some minor forms of development do not need planning permission. For the other applications, the local planning authority determines whether to grant approval, based on widespread consultation with interested parties, including those likely affected by the development in the local areas. An important part of the process, especially for major planning applications, is the pre-application discussions between developers and local authorities, as well as local communities.

If permission is refused, or if the local planning authority does not determine an application within a specific time, the applicant has the right to appeal the Secretary of State and the Planning Inspectorate will handle the appeal. In $2004 / 2005$ about $3 \%$ of all planning applications were appealed. A small number of planning applications will also be called-in each year and decided by the Secretary of State for Communities and Local Government. In 2005/2006 about 50 call-ins decisions were issued. $^{42}$

${ }^{42}$ Note that specific plans would exists for designated areas in the locality (e.g. World Heritage Sites, Special protection Areas, etc.) These sites will receive different levels of protection depending on their designation. There is a substantial proportion of designated land in England, with only $8.3 \%$ of total land is considered urban. 
More generally, the role of the Secretary of State is summarized as follows in the Barker Review:

- Making regulations, i.e. creation of statutory instruments to supplement the main planning legislation.

- Approval of some actions of local planning authorities, such as order of revocation or modification of planning permissions.

- Managing appeals of applications refused by local planning authorities, conditional grants or non-determinations within a given period.

- Powers of Directions, i.e. the ability to issue directions of a general and specific nature to planning authorities (e.g. call-in an application). This power is exercised sparingly, for example where a case gives rise to significant regional or national controversy.

- Advice and Guidance, i.e. issuance of Planning Policy Guidance Notes or Statements.

\section{Data Sources}

\section{A UK Census Data}

The data on independent retailers is drawn from the Inter Departmental Business Register (IDBR), which is at the base of most surveys run by the U.K. Census. The business register is compiled using a combination of tax records on VAT and PAYE, including information lodged at 
Companies House and Dun and Bradstreet. The IDBR captures two broad measures. First, it measures the structure of ownership of businesses using three aggregation categories: Local Units, Enterprises, and Enterprise Groups. A Local Unit is a single mailing address, so this is best thought of a store. An Enterprise is a chain of local units/shops under common ownership. An Enterprise Group is a group of enterprises under common ownership. Second, the IDBR holds turnover and employment data for both stores and firms. This is based mostly on tax data (plus old records from previous inquiries) — although generally the turnover data is deemed to be imprecise. The Annual Register Inquiry (ARI) is designed to maintain the business structure information on the IDBR. It began operation in July 1999 and is sent to large enterprises (over 100 employees) every year, to enterprises with 20-99 employees every four years, and to smaller enterprises on an ad hoc basis. The ARI currently covers around 68,000 enterprises, consisting of about 400,000 local units. It asks each enterprise for employment, industry activity, and the structure of the enterprise, including having to report employment of its local units. The first available year for the retail sample is 1997. However, this data is deemed to be imprecise and therefore the analysis starts in 1998. The geographical location of the stores is obtained matching a five-digit postcode with a dataset of geographical coordinates. I exclude from the sample stores that become part of retail chain at some point of their life. This is done to minimize measurement error in the independent store tag. The employment growth data is windsorized to the $1^{\text {st }}$ and $99^{\text {th }}$ percentile of the growth distributions (by retail type) to reduce the influence of extremely small or large variations in employment. This change involves a total of 36 observations, relative to 31 Local Authorities. The results shown throughout the paper are robust to the exclusion of these observations. 


\section{B ODPM Applications Database}

The data on major planning applications and grants were obtained from the Office of the Deputy Prime Minister (ODPM) - recently abolished. The ODPM was the main institution in charge of overseeing planning issues in England. For this purpose, the department kept detailed records of all the planning activity taking place across the country. The data used in this analysis was obtained upon a simple telephonic request. It includes all major (above 1,000 square meters) applications submitted and approved across all English Local Authorities between 1993 and 2003, classified under the category "Retail, distribution, and servicing." The data is anonymized and available only at the Local Authority-year level. The yearly number of major retail applications is windsorized to the $1^{\text {st }}$ and $99^{\text {th }}$ percentile of its distribution to reduce the influence of extreme application values. This change involves a total of 21 observations, relative to 13 Local Authorities. The results shown throughout the paper are robust to the exclusion of these observations.

\section{C British Local Elections Database}

The British Local Elections Database (BLED) is a unique source of information of local election results in Great Britain. It contains more than 150,000 individual election results since the 1973 wholesale local reorganization. The results are provided at the candidate level, and can be aggregated at the ward and at the Local Authority level via geographical identifiers. ${ }^{43}$

${ }^{43}$ Councils are divided into electoral divisions - known in district councils as "wards," and in county councils as "electoral divisions." Each ward can return one or more members-multimember wards are quite common. There is no requirement for the size of wards to be the same 
The aggregation is simplified by the fact that there is no proportional representation, i.e. the candidates that receive the most votes in the elections win. The variable used in the baseline regressions is the share of seats won by each party in the elections. In councils where the election takes place every four years, this variable coincides with the overall share of seats controlled in the council. In councils that elect a third of their councilors every year, this variable will only be proportional to the total share of seats in the council. The results are virtually identical using an estimate of the council composition. The only difference is that this introduces measurement error, since for some Local Authorities - which have experienced discrete jumps in the number of councillors - the estimate is particularly noisy.

\section{D Additional Data}

The core retail data is complemented by additional sources (Census 1991 and 2001, Annual Survey of Hours and Earnings, Labour Force Survey), which provide basic information on socioeconomic characteristics — such as population, income, and retail land prices - proxying for time varying demand characteristics.

\section{Robustness of the Results to Alternative Definitions of Small Formats}

Table A2 and A3 in Appendix show robustness of the main results of the paper using alternative classification methods to identify "small formats". The idea is to study the growth of

within a district, so one ward can return one member, and another ward can return two. Metropolitan borough wards must return a multiple of three councillors, while until the Local Government Act 2003 multiple-member county electoral divisions were forbidden. 
smaller stores that were opened by retail chains as a consequence of the new and more restrictive planning restrictions on big boxes. I identify firms exposed to planning regulation in two ways. The first method (which is the main used in the paper) isolates stores belonging a certain employment threshold (25, 28, 30 and 35 employees) and belonging to firms with at least 10,000 employees. These criteria are based on data (Haskel and Sadun, 2011) showing that very large retail firms typically open large stores. The second alternative method uses the same store level employment cutoffs, but considers stores belonging to any retail firm with at least one store with minimum 150 employees.

Table A2 investigates the relationship between a variable measuring the total number of independent stores in the postcode, and a dummy taking value one if the store is defined as a small formats. The specification is identical to the one used in Table 5, column 2, include local authority fixed effects and standard errors clustered at the postcode level. Column 1 reports the coefficient on the dummy variable, while column 2 reports the robust standard error. Small formats are more likely to be surrounded by independent stores relative to larger stores independently of the exact definition used. The coefficient on the small format dummy ranges from 0.3104 (where a store is defined as a small format if it belongs to a retail chain of at least one store with 150 employees, and has up to 28 employees) to 0.4469 where a store is defined as a small format if it belongs to a retail chain at least 10,000 employees, and has up to 35 employees), both significant at the $1 \%$ level.

Table A3 investigates the relationship between the employment growth of small formats and the number of planning grants given in the local authority. The specification is identical to the one used in Table 7, Panel A, column 6, and estimated via 2SLS using the share of Conservative seats in the Local Authority as instruments for planning grants. Column 1 reports the coefficient 
on the planning grant variable, while column 2 reports the robust standard error. Small formats are more likely to be surrounded by independent stores relative to larger stores independently of the exact definition used. The coefficient on planning is negative regardless of the precise definition for small formats, but it is generally precisely estimated only when the constraint on the parent firm having at least 10,000 employees is binding. This is consistent with the idea that regulation altered the entry strategy between large and small formats only of very large retail chains, i.e. those with at least 10,000 employees. When significant, the coefficient on planning grants ranges between -0.0170 (where a store is defined as a small format if it belongs to a retail chain of at least one store with 150 employees, and has up to 35 employees) to -0.0430 (where a store is defined as a small format if it belongs to a retail chain at least 10,000 employees, and has up to 35 employees). 
Figure 1 - Planning grants over Time

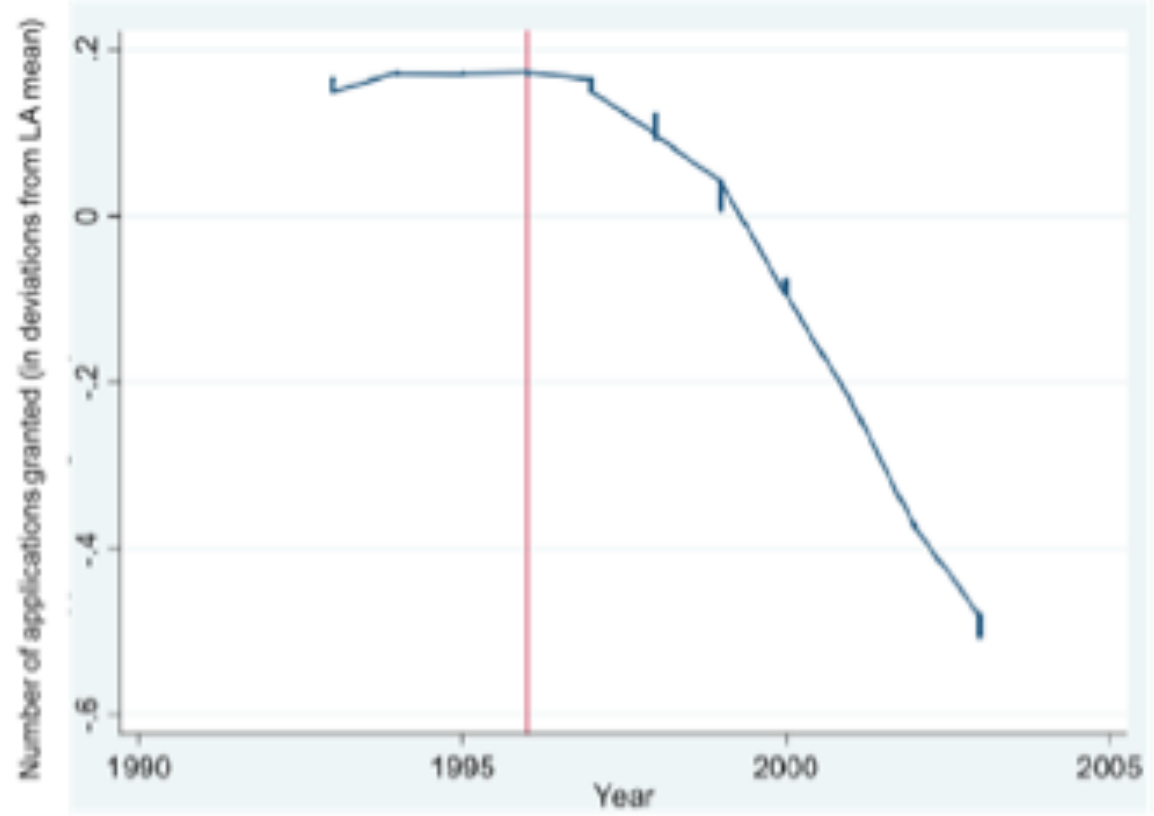

Note: The graph reports the lowess estimate (bandwidth 0.8 ) of the number of major retail applications granted across 305 English Local Authorities, observed between 1993 and 2003. The graph plots deviation from Local Authority means. 
Figure 2 - Average Number of Planning Grants across English Local Authorities (1993-2003)

Average Number Planning Grants

$3.27-15.36$

2.00-3.27

$1.18-2.00$

$0-1.18$

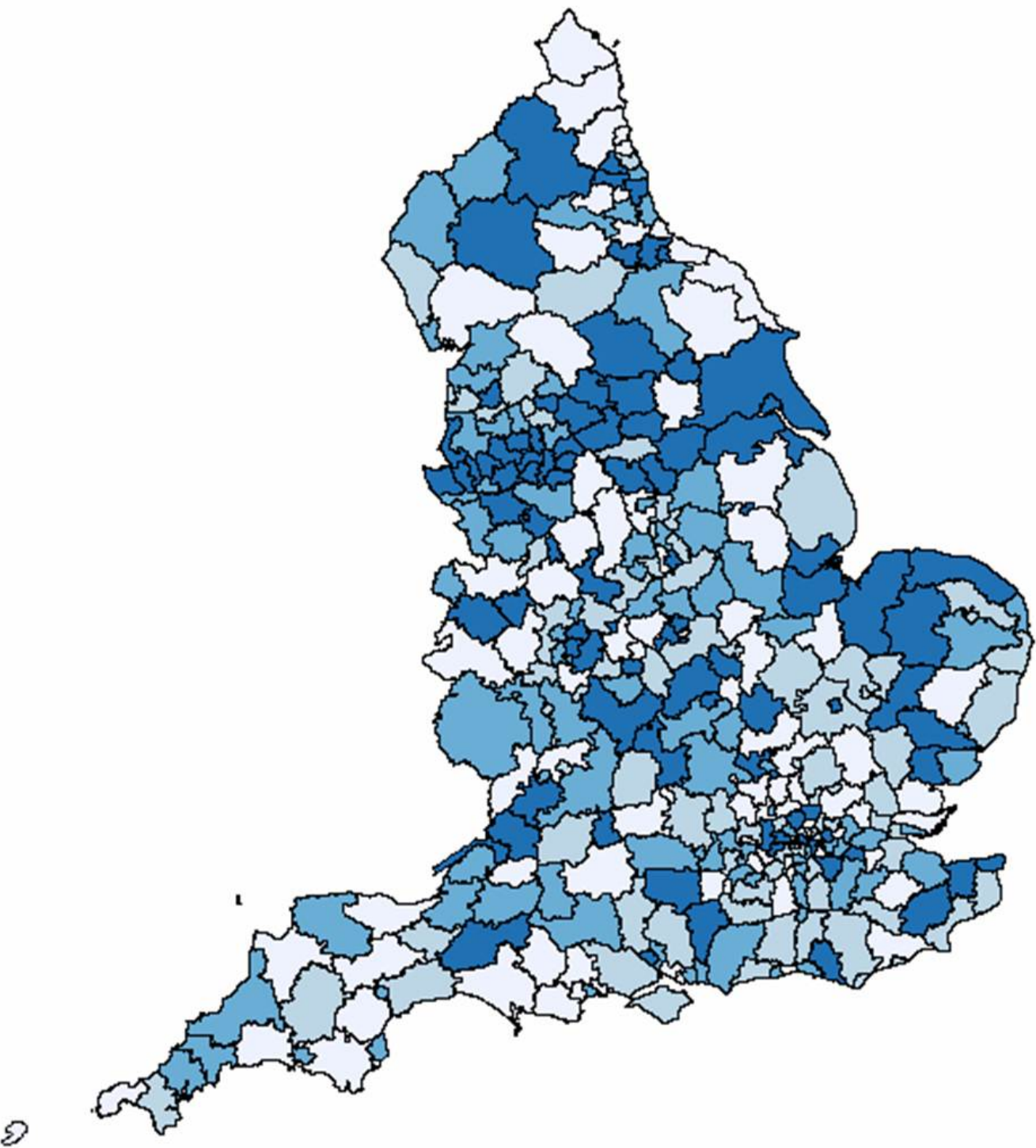

Notes: The map shows the average yearly number of planning grants given by 354 different English Local Authorities between 1993 and 2004. Source: ODPM data. 
Table 1 - Planning Grants at the Local Authority Level: Summary Statistics

\begin{tabular}{|c|c|c|c|}
\hline & Mean & Median & $\begin{array}{l}\text { Standard } \\
\text { Deviation }\end{array}$ \\
\hline $\begin{array}{l}\text { Planning Grants for Major Retail } \\
\text { Developments }\end{array}$ & 2.6 & 2 & 3.2 \\
\hline $\begin{array}{l}\text { Share of Major Retail Planning } \\
\text { Applications Granted }\end{array}$ & 0.84 & 1 & 0.27 \\
\hline Average Population (person) & 129,993 & 107,450 & 93,805 \\
\hline Population Density (person per ht) & 9.5 & 4.5 & 10.8 \\
\hline
\end{tabular}


Table 2 - Demand Drivers of Planning Grants

Dependent Variable: Planning Grants for Major Retail Developments

\begin{tabular}{|c|c|c|c|c|c|c|}
\hline $\operatorname{Ln}($ Pop) & $2.265^{* * *}$ & & & & & $2.230 * * *$ \\
\hline Log Population & $(0.255)$ & & & & & $(0.290)$ \\
\hline \%Urban & & $1.967 * * *$ & & & & -0.240 \\
\hline Percentage urban areas & & $(0.338)$ & & & & $(0.352)$ \\
\hline \%Young & & & $36.918 * * *$ & & & $16.704 * *$ \\
\hline Percentage people below 15 years & & & $(8.150)$ & & & $(7.316)$ \\
\hline $\operatorname{Ln}(W)$ & & & & -0.206 & & $-1.298 * *$ \\
\hline Log median hourly wages & & & & $(0.690)$ & & $(0.651)$ \\
\hline \%College & & & & & $-6.036 * * *$ & $-3.282 * *$ \\
\hline Percentage people with a college degree & & & & & $(1.695)$ & $(1.601)$ \\
\hline Observations & 3,318 & 3,318 & 3,318 & 3,318 & 3,318 & 3,318 \\
\hline
\end{tabular}

Notes: * significant at $10 \%$; ${ }^{* *}$ significant at $5 \%$; ${ }^{* *}$ significant at $1 \%$. The dependent variable in all columns is the number of major retail applications (above 1,000 square meters) granted by Local Authorities. All regressions include year dummies. The time period is 1993-2003. All estimates are based on 303 English Local Authorities. Errors are clustered at the Local Authority level. Sources: ODPM, Census 2001, LFS, ASHE. 
Table 3 - Political Drivers of Planning Grants

\begin{tabular}{|c|c|c|c|c|c|c|c|}
\hline & (1) & (2) & (3) & (4) & (5) & (6) & (7) \\
\hline \multicolumn{8}{|c|}{ Dependent Variable: Planning Grants for Major Retail Developments } \\
\hline Abs Maj Con & $-0.669 * * *$ & & & & & & \\
\hline Dummy Conservative Absolute Majority & $(0.175)$ & & & & & & \\
\hline Rel Maj Con & & $-0.719 * * *$ & & & & & \\
\hline Dummy Conservative Relative Majority & & $(0.177)$ & & & & & \\
\hline Sha_CON & & & $-1.868 * * *$ & $-1.370 * * *$ & $-1.713^{* * *}$ & $-0.864 *$ & $-0.686 *$ \\
\hline Share of seats won by Conservative Party & & & $(0.476)$ & $(0.375)$ & $(0.420)$ & $(0.470)$ & $(0.402)$ \\
\hline Sha_LD & & & & & -0.738 & & \\
\hline Share of seats won by Liberal Democrats & & & & & $(0.473)$ & & \\
\hline Sha_Other & & & & & -0.866 & & \\
\hline Share of seats won by Other Parties & & & & & $(0.601)$ & & \\
\hline Observations & 3,318 & 3,318 & 3,318 & 3,318 & 3,318 & 3,318 & 3,318 \\
\hline Controls & - & - & - & a & a & $\mathbf{a}$ & a \\
\hline Lacal Authority fixed effects & & & & & & Yes & Yes \\
\hline Local Authority trends & & & & & & & Yes \\
\hline Omitted group & $\begin{array}{l}\text { Other } \\
\text { absolute } \\
\text { majorities } \\
\text { and no } \\
\text { absolute } \\
\text { majorities }\end{array}$ & $\begin{array}{c}\text { Other } \\
\text { parties' } \\
\text { relative } \\
\text { majorities }\end{array}$ & $\begin{array}{l}\text { All other } \\
\text { parties' } \\
\text { shares }\end{array}$ & $\begin{array}{c}\text { All other } \\
\text { parties' } \\
\text { shares }\end{array}$ & $\begin{array}{l}\text { Labour } \\
\text { party's } \\
\text { share }\end{array}$ & $\begin{array}{l}\text { All other } \\
\text { parties' } \\
\text { shares }\end{array}$ & $\begin{array}{c}\text { All other } \\
\text { parties' } \\
\text { shares }\end{array}$ \\
\hline
\end{tabular}

Notes: ${ }^{*}$ significant at $10 \% ;{ }^{* *}$ significant at $5 \% ;{ }^{* *}$ significant at $1 \%$. The dependent variable in all columns is the number of major retail applications (above 1,000 square meters) granted by Local Authorities. The time period is 1993-2003. All estimates are based on 303 English Local Authorities. Errors are clustered at the Local Authority level. All columns include year dummies. Control "a" includes the log of population), the fraction of urban and village areas, the log median hourly wage, the percentage of people below 15 years, and the percentage of people with a college degree (NSV 3 or 4, measured in 2001) in the Local Authority. Column (4) includes Local Authority fixed effects and (5) includes Local Authority trends. All regressions weighted by the share of population in the Local Authority. Sources: ODPM, BLED, Census 2001, LFS, ASHE. 
Panel A: Large Chains (multiestablishment firms with more than 10,000 Employees)

\begin{tabular}{|c|c|c|c|c|c|}
\hline \multirow[b]{2}{*}{ Year } & \multirow{2}{*}{$\begin{array}{c}\text { Total } \\
\text { Employment }\end{array}$} & \multirow{2}{*}{$\begin{array}{c}\text { Total } \\
\text { Number of } \\
\text { Stores } \\
\end{array}$} & \multicolumn{3}{|c|}{ Store size distribution (employees) } \\
\hline & & & $\begin{array}{c}\text { 25th } \\
\text { Percentile }\end{array}$ & Median & $\begin{array}{c}\text { 75th } \\
\text { Percentile }\end{array}$ \\
\hline 1998 & 804406.30 & 8481.00 & 18.00 & 33.00 & 114.00 \\
\hline 2004 & 983094.00 & 10611.00 & 15.00 & 28.00 & 92.00 \\
\hline \% Change 1998 to 2004 & $22.21 \%$ & $25.11 \%$ & $-16.67 \%$ & $-12.12 \%$ & $-19.30 \%$ \\
\hline \multicolumn{6}{|c|}{ Panel A: Small Chains (multiestablishment firms with less than 10,000 Employees) } \\
\hline & $\begin{array}{c}\text { Total } \\
\text { Employment }\end{array}$ & $\begin{array}{c}\text { Total } \\
\text { Number of } \\
\text { Stores }\end{array}$ & \multicolumn{3}{|c|}{ Store size distribution (employees) } \\
\hline & & & $\begin{array}{c}\text { 25th } \\
\text { Percentile }\end{array}$ & Median & $\begin{array}{c}\text { 75th } \\
\text { Percentile }\end{array}$ \\
\hline 1998 & 198609.30 & 10681.00 & 6.00 & 17.00 & 30.00 \\
\hline 2004 & 171796.00 & 8815.00 & 6.00 & 18.00 & 32.00 \\
\hline \% Change 1998 to 2004 & $-13.50 \%$ & $-17.47 \%$ & $0.00 \%$ & $5.88 \%$ & $6.67 \%$ \\
\hline \multicolumn{6}{|c|}{ Panel C: Independent stores (single establishment firms) } \\
\hline & $\begin{array}{c}\text { Total } \\
\text { Employment }\end{array}$ & $\begin{array}{c}\text { Total } \\
\text { Number of } \\
\text { Stores }\end{array}$ & \multicolumn{3}{|c|}{ Store size distribution (employees) } \\
\hline Year & & & $\begin{array}{c}\text { 25th } \\
\text { Percentile }\end{array}$ & Median & $\begin{array}{c}\text { 75th } \\
\text { Percentile }\end{array}$ \\
\hline 1998 & 129736.30 & 38388.00 & 2.00 & 2.00 & 4.00 \\
\hline 2004 & 120181.00 & 35322.00 & 2.00 & 2.00 & 4.00 \\
\hline \% Change 1998 to 2004 & $-7.37 \%$ & $-7.99 \%$ & $0.00 \%$ & $0.00 \%$ & $0.00 \%$ \\
\hline
\end{tabular}

Notes: The summary statistics reported in this table are computed from store level IDRB data for the sector "Non Specialized Retail" (SIC 521), 1998 and 2004. 


\section{(1)}

Dependent Variable:

\section{Dummy Small Format}

Dummy=1 if store has fewer than 28

employees and belongs to a large chain (>10,000 employees)

Observations

12559
Number of chain stores Number of independent in the postcode

$-1.0362 * * *$

(0.1745)
(2) stores in the postcode

$0.3811^{* * *}$

(0.0391)

Local Authority Fixed Effects 12559

Yes

Yes

Notes: The sample for these regressions is the set of all stores belonging to retail chains with at least 10,000 employees. The dependent variable in column 1 is the number of stores in the same postcode belonging to retail chains, the dependent variable in column 2 is the number of stores in the same postocde belonging to independent retailers. Stores are identified as "small formats" is they have less than 28 employees. All columns include Local Authority fixed effects, standard errors clustered at the postcode level. All regressions estimated by OLS. 
Table 6 - Planning Grants and Retail Employment

Dependent variable: Employment Growth (Local Authority aggregate)

(1)

(2)

(3)

(4)

(5)

(6)

(7)

Type of Firms

Large Retail Chains

Independents

Small Retail Manufacturing Chains

\begin{tabular}{|c|c|c|c|c|c|c|c|}
\hline Type of Stores & All stores & $\begin{array}{c}\text { Large } \\
\text { formats }\end{array}$ & $\begin{array}{c}\text { Small } \\
\text { formats }\end{array}$ & All stores & All stores & All stores & All plants \\
\hline \multicolumn{8}{|l|}{ Planning Grants for Major } \\
\hline Retail Developments $\mathrm{s}_{\mathrm{t}-2}$ & $\begin{array}{c}0.0029 * * * \\
(0.0009)\end{array}$ & $\begin{array}{c}0.0036^{* * *} \\
(0.0010)\end{array}$ & $\begin{array}{c}-0.0059 * * * \\
(0.0022)\end{array}$ & $\begin{array}{c}0.0017^{* *} \\
(0.0008)\end{array}$ & & $\begin{array}{c}0.0024 \\
(0.0027)\end{array}$ & $\begin{array}{c}-0.0008 \\
(0.0013)\end{array}$ \\
\hline $\begin{array}{l}\text { Employment growth of small } \\
\text { formats }\end{array}$ & & & & & $\begin{array}{l}-0.0135^{*} \\
(0.0077)\end{array}$ & & \\
\hline $\operatorname{Ln}($ Pop) & $-0.0147^{* * *}$ & $-0.0188 * * *$ & $0.0246^{* *}$ & -0.0000 & 0.0049 & 0.0140 & 0.5771 \\
\hline Log Population & (0.0051) & (0.0057) & (0.0119) & $(0.0050)$ & (0.0045) & (0.0148) & (0.7037) \\
\hline Observations & 1764 & 1764 & 1764 & 1764 & 1764 & 1764 & 1478 \\
\hline Controls & $\mathrm{a}$ & $a$ & $a$ & $a$ & $a$ & $a$ & $a$ \\
\hline
\end{tabular}

Notes: ${ }^{*}$ significant at $10 \%$; ${ }^{* *}$ significant at $5 \% ; * * *$ significant at $1 \%$. The dependent variable in all columns is the one year log employment growth of all stores belonging to large retail chains (column 1), stores belonging to large retail chains above 28 employees (column 2 ), stores belonging to large retail chains with less than 28 employees (column 3), independent retailers (columns 4 and 5), small retail chains (column 6), manufacturing (column 7). The time period is 1998-2004. All estimates are based on 303 English Local Authorities. Errors are clustered at the Local Authority level. All columns include year dummies. Control "a" includes the log of population, the fraction of urban and village areas, the log median hourly wage, the percentage of people below 15 years, and the percentage of people with a college degree (NSV 3 or 4 , measured in 2001) in the Local Authority. All regressions weighted by the share of population in the Local Authority. 


\begin{tabular}{|c|c|c|c|c|c|}
\hline & (1) & (2) & (3) & (4) & (5) \\
\hline $\begin{array}{l}\text { Estimation method } \\
\text { Planning Grants for Major }\end{array}$ & OLS & OLS & OLS & OLS & $2 S L S$ \\
\hline Retail Developments $\mathrm{t}_{\mathrm{t}-2}$ & $\begin{array}{c}-0.0059 * * * \\
(0.0022)\end{array}$ & $\begin{array}{r}-0.0055^{* *} \\
(0.0022)\end{array}$ & $\begin{array}{l}-0.0065^{*} \\
(0.0038)\end{array}$ & & $\begin{array}{r}-0.0355^{* *} \\
(0.0171)\end{array}$ \\
\hline Share of Conservative Seats $\mathrm{t}_{\mathrm{t}-2}$ & & & & $\begin{array}{r}0.0614^{* *} \\
(0.0262)\end{array}$ & \\
\hline $\operatorname{Ln}($ Pop) & $0.0246^{* *}$ & $0.0233^{*}$ & -0.1312 & 0.0114 & $0.1091 * *$ \\
\hline Log Population & $(0.0119)$ & $(0.0130)$ & $(0.7052)$ & $(0.0108)$ & $(0.0512)$ \\
\hline Observations & 1764 & 1764 & 1764 & 1764 & 1764 \\
\hline Controls & $\bar{a}$ & $\mathrm{~b}$ & $\bar{a}$ & $\bar{a}$ & $\bar{a}$ \\
\hline \multicolumn{2}{|l|}{ Local Authority Fixed Effects } & & Yes & & \\
\hline \multicolumn{3}{|c|}{ Kleinbergen-Paap rk Wald F statistic } & & & 10.215 \\
\hline
\end{tabular}

Panel B: Dependent variable: Employment Growth of Independent retailers (Local Authority aggregate)

\begin{tabular}{|c|c|c|c|c|c|}
\hline & (1) & (2) & (3) & (4) & (5) \\
\hline $\begin{array}{l}\text { Estimation method } \\
\text { Planning Grants for Major }\end{array}$ & OLS & OLS & OLS & OLS & 2SLS \\
\hline Retail Developments $_{\mathrm{t}-2}$ & $\begin{array}{r}0.0017^{* *} \\
(0.0008)\end{array}$ & $\begin{array}{l}0.0018^{* *} \\
(0.0008)\end{array}$ & $\begin{array}{l}0.0027^{*} \\
(0.0015)\end{array}$ & & $\begin{array}{l}0.0119 * \\
(0.0066)\end{array}$ \\
\hline Share of Conservative Seats $\mathrm{s}_{\mathrm{t}-2}$ & & & & $\begin{array}{c}-0.0205^{* *} \\
(0.0093)\end{array}$ & \\
\hline $\operatorname{Ln}($ Pop) & -0.0000 & 0.0013 & 0.3025 & 0.0035 & -0.0291 \\
\hline Log Population & $(0.0050)$ & $(0.0051)$ & $(0.2781)$ & $(0.0044)$ & $(0.0190)$ \\
\hline Observations & 1764 & 1764 & 1764 & 1764 & 1764 \\
\hline Controls & $\mathrm{a}$ & $\mathrm{b}$ & $\mathrm{a}$ & $a$ & $a$ \\
\hline \multicolumn{2}{|l|}{ Local Authority Fixed Effects } & & Yes & & \\
\hline \multicolumn{3}{|c|}{ Kleinbergen-Paap rk Wald F statistic } & & & 10.215 \\
\hline
\end{tabular}

Notes: * significant at $10 \% ;{ }^{* *}$ significant at $5 \% ;{ }^{* * *}$ significant at $1 \%$. The dependent variable in all columns of Panel $\mathrm{A}$ is the one year log employment growth of all stores belonging to large retail chains with less than 28 employees. The dependent variable in all columns of Panel B is the one year log employment growth of all independent retailers. The time period is 1998-2004. All estimates are based on 303 English Local Authorities. Errors are clustered at the Local Authority level. All columns include year dummies. All columns estimated by OLS, except for column 6, which is estimated by 2 SLS (planning grants are instrumented with the share of seats won by Conservative councilors in the Local Authority at time t-2). Control "a" includes the log of population, the fraction of urban and village areas, the log median hourly wage, the percentage of people below 15 years, and the percentage of people with a college degree (NSV 3 or 4, measured in 2001) in the Local Authority. Control "b" includes "a", plus the percentage of people working in manufacturing and retail, an interaction term between log median hourly wage and a dummy equal to unity for any year after 1999 (this is to capture the possible differential effects of the minimum wage introduction), and the log of the total area (in hectares) covered by the Local Authority.All regressions weighted by the share of population in the Local Authority. 
Table 8 - Margins of Adjustment

\begin{tabular}{|c|c|c|c|c|}
\hline \multicolumn{5}{|c|}{ Panel A: Dependent variable: DHS decomposition of the Employment Growth of Small Formats (Local Authority aggregate) } \\
\hline & (1) & (2) & (3) & (4) \\
\hline \multicolumn{5}{|l|}{ Estimation method: $2 S L S$} \\
\hline & & & Incumbents' & Incumbents' \\
\hline Growth Margin & Entry & Exit & Expansion & Contraction \\
\hline \multirow[t]{2}{*}{ Planning Grants for Major Retail Developments $\mathrm{t}_{-2}$} & $-0.0571 * *$ & 0.0096 & -0.0049 & -0.0052 \\
\hline & $(0.0264)$ & $(0.0142)$ & $(0.0043)$ & (0.0033) \\
\hline Ln(Pop) & $0.1460^{*}$ & -0.0297 & 0.0193 & $0.0184^{*}$ \\
\hline Log Population & $(0.0798)$ & $(0.0417)$ & $(0.0129)$ & $(0.0096)$ \\
\hline Observations & 1759 & 1759 & 1759 & 1759 \\
\hline Controls & $a$ & $a$ & $a$ & $\mathrm{a}$ \\
\hline \multicolumn{5}{|c|}{ Panel B: Dependent variable: DHS decomposition of the Employment Growth of Independent retailers (Local Authority aggregate } \\
\hline & (2) & (3) & (4) & (5) \\
\hline \multicolumn{5}{|l|}{ Estimation method: 2SLS } \\
\hline & & & Incumbents' & Incumbents' \\
\hline Growth Margin & Entry & Exit & Expansion & Contraction \\
\hline \multirow[t]{2}{*}{ Planning Grants for Major Retail Developments $\mathrm{t}_{-2}$} & -0.0087 & $-0.0264 *$ & 0.0024 & -0.0013 \\
\hline & (0.0089) & $(0.0141)$ & (0.0029) & $(0.0022)$ \\
\hline $\operatorname{Ln}($ Pop) & 0.0391 & $0.0794^{*}$ & -0.0074 & 0.0045 \\
\hline Log Population & $(0.0263)$ & $(0.0413)$ & $(0.0090)$ & (0.0064) \\
\hline Observations & 1763 & 1763 & 1763 & 1763 \\
\hline Controls & $a$ & $a$ & $a$ & $a$ \\
\hline
\end{tabular}

Notes: * significant at $10 \% ;{ }^{* *}$ significant at $5 \% ; * *$ significant at $1 \%$. The time period is $1998-2004$. All estimates are based on 303 English Local Authorities. The dependent variables are the different components of employment growth of small formats (Panel A) and independent retailers (Panel B), computed using the Davis and Haltiwanger (1992) formula. All columns include year dummies. Control "a" includes the log of population, the fraction of urban and village areas, the log median hourly wage, the percentage of people below 15 years, and the percentage of people with a college degree (NSV 3 or 4, measured in 2001) in the Local Authority. Errors are clustered at the Local Authority level. All regressions estimated by 2SLS using the share of seats won by Conservative councilors in the Local Authority at time t-2 to instrument for the number of planning grants at $\mathrm{t}-2$ as in Table 7 , column 5 . All regressions are weighted by the share of population in the Local Authority. 
Table 9 - Robustness on IV Estimates

Panel A - Small Formats

Experiment

Baseline IV Cumulate Employment 2 years

grants

in levels and averages

Local

Authority

Fixed Effects

verages

\begin{tabular}{|c|c|c|c|}
\hline $\begin{array}{c}\text { Control for } \\
\text { total } \\
\text { employment } \\
\text { growth in LA }\end{array}$ & $\begin{array}{c}\text { Control for } \\
\text { major grants } \\
\text { in } \\
\text { neighboring } \\
\text { Local } \\
\text { Authorities }\end{array}$ & $\begin{array}{c}\text { Control for } \\
\text { exit of } \\
\text { large } \\
\text { stores }\end{array}$ & $\begin{array}{c}\text { Use national } \\
\text { elections in } \\
\text { IV }\end{array}$ \\
\hline
\end{tabular}

Estimation method: 2SLS

Planning Grants for Major Retail

Developments $_{\mathrm{t}-2}$

(1)

$-0.0355^{* *}$

(0.0171)

Sum of Planning Grants for Major

Retail Developments between t-3

and t-1

Sum of Planning Grants for Major Retail Developments between 1993 and t-2

Planning Grants for Major Retail

Developments $s_{t-2}, 2$ years average

Total Employment Growth

Planning Grants for Major Retail

Developments $_{t-2}$, neighboring Local

Authorities

Number of exiting stores with more

than 150 employees ${ }_{t}$

Ln(Pop)
Log Population
Observations

Controls

Kleinbergen-Paap rk Wald F statistic
(2)

$\begin{array}{ccccc}\text { (4) } & \mathbf{( 5 )} & \mathbf{( 6 )} & \mathbf{( 7 )} & \mathbf{( 8 )} \\ & & & \\ & -0.0376^{* *} & -0.0340^{*} & -0.0340^{* *} & -0.0729 * \\ & (0.0184) & (0.0178) & (0.0169) & (0.0399)\end{array}$

$-0.0116^{* *}$

(0.0052)

$\begin{array}{cc}(1) & (2) \\ -0.0355^{* *} & \\ (0.0171) & \\ & -0.0116^{* *} \\ & (0.0052)\end{array}$

$-0.0143^{* *}$

(0.0067)

$-0.0319 *$

(0.0170)

0.0514

(0.0412)

Notes: * significant at 10\%; ** significant at 5\%; *** significant at $1 \%$. The time period is $1998-2004$. All estimates are based on 303 English Local Authorities. Panel (A) refers to all stores belonging to large retail chains (more than 10,000 employees) with less than 28 employees, Panel (B) refers to independent retailers. The dependent variable in columns 1, 2, 5, 6, 7 and 8 is the log yearly employment growth. The dependent variable in column 3 is log employment in levels. The dependent variable in column 4 is a two year average of the employment growth. All columns include year dummies. Control "a" includes the log of population, the fraction of urban and village areas, the log median hourly wage, the percentage of people below 15 years, and the percentage of people with a college degree (NSV 3 or 4, measured in 2001) in the Local Authority. Errors are clustered at the Local Authority level. All regressions estimated by 2SLS using as an instrument for major planning grants the share of seats won by Conservative councilors in the Local Authority at time t-2 (or transfomations analoguous to the ones made to planning grants), except for column 8 , where the instrument is the share of votes going to the Conservative party in national elections (interpolated between election years). All regressions are weighted by the share of population in the Local Authority. 
Table 9 - Robustness on IV Estimates

Panel B - Independents

Experiment

Baseline IV Cumulate Employment 2 years

grants in levels and averages

Local

Authority

Fixed Effects

Estimation method: 2SLS

\begin{tabular}{|c|c|c|c|c|c|c|c|c|}
\hline & (1) & (2) & (3) & (4) & (5) & (6) & (7) & (8) \\
\hline \multicolumn{9}{|l|}{ Planning Grants for Major Retail } \\
\hline \multirow[t]{2}{*}{ Developments $_{\mathrm{t}-2}$} & $0.0119 *$ & & & & $0.0128^{*}$ & $0.0134^{*}$ & $0.0117^{*}$ & 0.0049 \\
\hline & $(0.0066)$ & & & & $(0.0070)$ & $(0.0072)$ & $(0.0065)$ & $(0.0070)$ \\
\hline \multicolumn{9}{|l|}{ Sum of Planning Grants for Major } \\
\hline \multicolumn{9}{|l|}{ Retail Developments between t-3 } \\
\hline \multirow[t]{2}{*}{ and $\mathrm{t}-1$} & & $0.0036^{*}$ & & & & & & \\
\hline & & $(0.0021)$ & & & & & & \\
\hline \multirow{2}{*}{\multicolumn{9}{|c|}{$\begin{array}{l}\text { Sum of Planning Grants for Major } \\
\text { Retail Developments between } 1993\end{array}$}} \\
\hline & & & & & & & & \\
\hline \multirow[t]{2}{*}{ and $\mathrm{t}-2$} & & & 0.0045 & & & & & \\
\hline & & & $(0.0028)$ & & & & & \\
\hline \multicolumn{9}{|l|}{ Planning Grants for Major Retail } \\
\hline \multirow[t]{2}{*}{ Developments $_{\mathrm{t}-2}, 2$ years average } & & & & $0.0120^{*}$ & & & & \\
\hline & & & & $(0.0067)$ & & & & \\
\hline \multirow[t]{2}{*}{ Total Employment Growth } & & & & & $-0.0214^{*}$ & & & \\
\hline & & & & & $(0.0128)$ & & & \\
\hline \multicolumn{9}{|l|}{ Planning Grants for Major Retail } \\
\hline \multicolumn{9}{|l|}{ Developments $_{t-2,}$ neighboring Local } \\
\hline \multirow[t]{2}{*}{ Authorities } & & & & & & $-0.0006 * *$ & & \\
\hline & & & & & & $(0.0003)$ & & \\
\hline \multicolumn{9}{|l|}{ Number of exiting stores with more } \\
\hline \multirow[t]{2}{*}{ than 150 employees $_{t}$} & & & & & & & 0.0036 & \\
\hline & & & & & & & $(0.0045)$ & \\
\hline $\operatorname{Ln}($ Pop) & -0.0291 & -0.0289 & 0.1281 & -0.0286 & -0.0122 & -0.0279 & -0.0296 & -0.0096 \\
\hline Log Population & $(0.0190)$ & $(0.0197)$ & $(0.3441)$ & $(0.0192)$ & $(0.0174)$ & $(0.0191)$ & $(0.0192)$ & $(0.0197)$ \\
\hline Observations & 1764 & 1747 & 2051 & 887 & 1764 & 1764 & 1764 & 1757 \\
\hline Controls & $\mathrm{a}$ & $a$ & $\mathrm{a}$ & $\mathrm{a}$ & a & $\mathrm{a}$ & a & $a$ \\
\hline Kleinbergen-Paap rk Wald F statistic & 10.215 & 10.029 & 16.565 & 9.596 & 8.897 & 9.351 & 10.354 & 3.339 \\
\hline
\end{tabular}

Notes: * significant at $10 \% ; *$ significant at $5 \% ; * *$ significant at $1 \%$. The time period is $1998-2004$. All estimates are based on 303 English Local Authorities. Panel (A) refers to all stores belonging to large retail chains (more than 10,000 employees) with less than 28 employees, Panel (B) refers to independent retailers. The dependent variable in columns 1, 2, 5, 6, 7 and 8 is the log yearly employment growth. The dependent variable in column 3 is log employment in levels. The dependent variable in column 4 is a two year average of the employment growth. All columns include year dummies. Control "a" includes the log of population, the fraction of urban and village areas, the log median hourly wage, the percentage of people below 15 years, and the percentage of people with a college degree (NSV 3 or 4, measured in 2001) in the Local Authority. Errors are clustered at the Local Authority level. All regressions estimated by 2SLS using as an instrument for major planning grants the share of seats won by Conservative councilors in the Local Authority at time t-2 (or transfomations analoguous to the ones made to planning grants), except for column 8 , where the instrument is the share of votes going to the Conservative party in national elections (interpolated between election years). All regressions are weighted by the share of population in the Local Authority. 
Table A1: Additional Summary Statistics

\begin{tabular}{lccc}
\hline Variable & Mean & Median & $\begin{array}{c}\text { Standard } \\
\text { Deviation }\end{array}$ \\
Planning Grants $_{\text {t-2 }}$ & 2.45 & 2 & 2.86 \\
Share of Conservatives $_{\text {t-2 }}$ (2001 & 0.31 & 0.3 & 0.22 \\
Population Growth 1991-22 & 0.01 & 0.01 & 0.01 \\
Fraction of population below 15 years & 0.19 & 0.19 & 0.01 \\
Hourly wage (f) & 7.97 & 7.76 & 1.3 \\
Fraction of population with a college degree in 2001 & 0.18 & 0.18 & 0.05 \\
Fraction of Urban Areas & 0.7 & 0.74 & 0.27 \\
Fraction of Village Areas & 0.15 & 0.1 & 0.16 \\
\hline
\end{tabular}

Notes: These summary statistics refer to the estimation sample $(1,815$ observations, 303 Local Authorities, 1998-2004). Sources: IDBR, ODPM, BLED, Census 1991 and 2001, ASHE. 
Table A2: Independent stores density and Small Formats using alternative ways to identify small formats

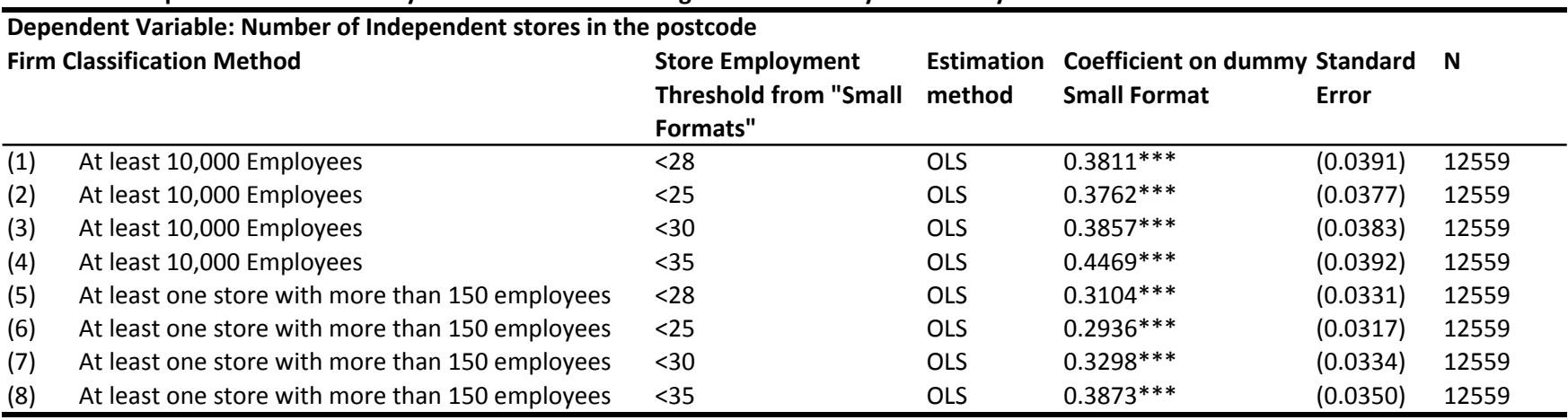

Notes: Each line corresponds to a different regression. The sample for the regressions in rows 1 to 4 is the set of all stores belonging to retail chains with at least 10,000 employees. The sample for the regressions in rows 5 to 8 is the set of all stores belonging to retail chains with at least one store with 150 employees. The dependent variable in all rows is the number of stores in the same postcode belonging to independent retailers. The definition for small formats varies in each row as noted. All columns include Local Authority fixed effects, standard errors clustered at the postcode level. All regressions estimated by OLS.

Table A3: Correlation between small formats and planning grants using alternative ways to identify small formats

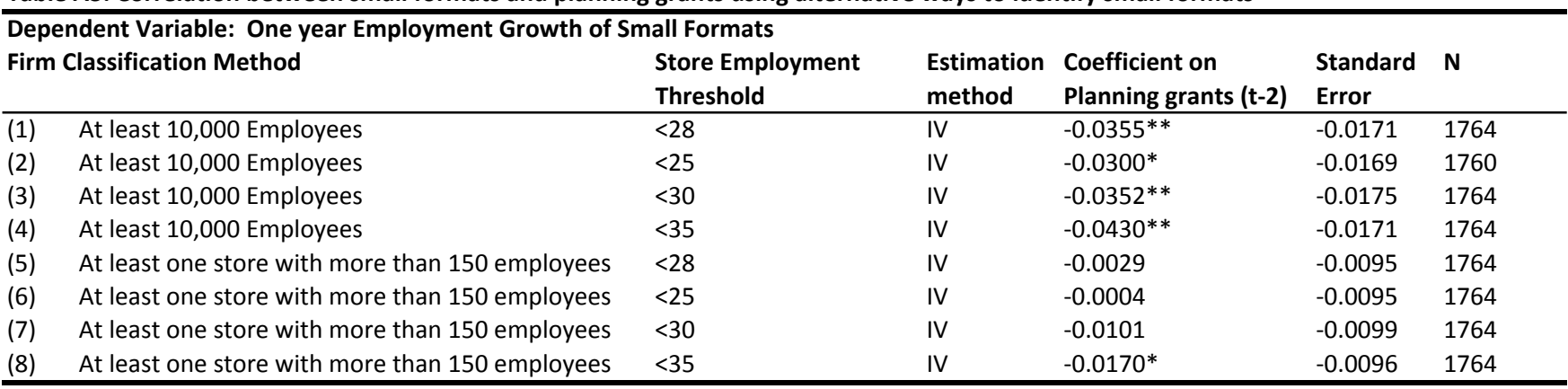

Notes: Each line corresponds to a different regression. The dependent variable in all regressions is the yearly log growth of small retail formats. The definition of small formats varies in each row as noted. The time period is 1998-2004. All estimates are based on 303 English Local Authorities. Errors are clustered at the Local Authority level. All columns include year dummies, the log of population, the fraction of urban and village areas, the log median hourly wage, the percentage of people below 15 years, and the percentage of people with a college degree (NSV 3 or 4, measured in 2001) in the Local Authority. All regressions estimated by 2SLS (planning grants are instrumented with the share of seats won by Conservative councilors in the Local Authority at time $\mathrm{t}-2$ ). All regressions weighted by the share of population in the Local Authority. 